\title{
Spatial Variation of Magnitude Scaling Factors During the 2010 Darfield and 2011 Christchurch, New Zealand, Earthquakes
}

\author{
W.L. Carter $^{1}$, R.A. Green ${ }^{1}$, B.A. Bradley ${ }^{2}$, L.M. Wotherspoon ${ }^{3}$, and M. Cubrinovski ${ }^{2}$ \\ ${ }^{1}$ Department of Civil and Environmental Engineering, Virginia Tech, Blacksburg, Virginia, U.S.A.; \\ lakec@vt.edu; rugreen@vt.edu \\ 2 Department of Civil and Natural Resources Engineering, University of Canterbury, Christchurch, New \\ Zealand; brendon.bradley@canterbury.ac.nz; misko.cubrinovski@canterbury.ac.nz \\ ${ }^{3}$ Department of Civil and Environmental Engineering, University of Auckland, Auckland, New Zealand; \\ 1.wotherspoon@auckland.ac.nz
}

Abstract: The combination of well-documented liquefaction response during the Darfield and Christchurch, New Zealand, earthquakes, densely-recorded ground motions for the events, and detailed subsurface characterization provides an unprecedented opportunity to investigate the significance of the spatial variation of magnitude scaling factors (MSF) on liquefaction triggering. Towards this end, MSF were computed at 15 SMS sites across Christchurch and its surroundings using two established approaches. Trends in the spatial variation of the MSF computed using number of equivalent cycles $\left(\mathrm{n}_{\text {eq }}\right)$ from both approaches were similar, with the spatial variation being more significant for the Christchurch earthquake than the Darfield earthquake. However, there was no consistent trend for regions with lower computed MSF having experienced more severe or widespread liquefaction. Additionally, there is a general correlation between MSF and $\mathrm{a}_{\max }$, but because $\mathrm{a}_{\max }$ ranges more widely than MSF it has a greater influence on the resulting seismic demand imposed on the soil than MSF does. Nevertheless, the spatial variation of the MSF is deemed significant enough that it warrants being considered for incorporation into future variants of simplified liquefaction evaluation procedures.

Keywords: liquefaction; magnitude scaling factors; Christchurch; Canterbury earthquakes 


\section{Introduction}

2 The objective of the study presented herein is to assess the significance of the spatial variation of the

3 magnitude scaling factors across Christchurch, New Zealand, and its environs on the assessment of

4 liquefaction triggering during the 2010 Darfield and 2011 Christchurch earthquakes. Liquefaction is a

5 phenomenon that generally occurs in loose to medium dense saturated cohesionless soil subjected to

6 cyclic loading. It results from the contractive tendency of the soil skeleton during shaking and the

7 consequential transfer of the overburden stress from the soil skeleton to the pore fluid. The "simplified"

8 liquefaction triggering evaluation procedure is a total stress framework that was originally developed by

9 Whitman (1971) and Seed and Idriss (1971) and has been continually revised as a result of the increase in

10 the number of field case histories, etc. (e.g., Youd et al., 2001; Cetin et al., 2004; Idriss and Boulanger,

11 2008). In this procedure, the durational effects of the ground motions are accounted for by magnitude

12 scaling factors (MSF), which traditionally have only been correlated to earthquake magnitude (e.g., Youd

13 et al., 2001; Cetin et al., 2004; Idriss and Boulanger, 2008). As a result, within the context of the

14 simplified procedure, the spatial variation in the seismic demand imposed on the soil traditionally has

15 been assumed to be solely a function of the spatial variation of the peak amplitude of the ground motions

16 and the characteristics of the soil profile. However, these traditional assumptions fail to appreciate the

17 inverse correlation between the peak amplitude of ground motions and strong ground motion duration.

18 The extreme cases of this are motions with forward versus reverse directivity effects, where the former

19 tend to have higher amplitudes and shorter durations and the latter tend to have the opposite trends

20 (Archuleta and Hartzell, 1984; Somerville et al., 1997). Additionally, it is known that ground motion

21 duration varies with site-to-source distance (e.g., Bommer and Martinez-Pereira, 1999; Kempton and

22 Stewart, 2006; Stafford et al., 2009; Lee and Green, 2014), and thus, it would be expected that MSF will

23 also vary with distance from the source.

25 Christchurch, New Zealand, and its surroundings experienced widespread liquefaction as a result of the 26 2010-2011 Canterbury Earthquake Sequence (CES) (e.g., Cubrinovski and Green, 2010; Cubrinovski et 
27 al., 2011; Green et al., 2014). However, of the 10 events in the CES that are known to have caused

28 liquefaction (Quigley et al., 2013), the 4 September 2010, $\mathrm{M}_{\mathrm{w}} 7.1$ Darfield and 22 February 2011, $\mathrm{M}_{\mathrm{w}} 6.2$

29 Christchurch earthquakes were the most significant (Figure 1). The combination of well-documented

30 liquefaction response during the Darfield and Christchurch earthquakes, densely-recorded ground motions

31 for the events, and detailed subsurface characterization provides an unprecedented opportunity to

32 investigate the significance of the spatial variation of MSF on liquefaction triggering. Of particular

33 relevance to this study is that directivity effects were prevalent in the ground motions recorded during the

34 Darfield earthquake, and to a much lesser extent, during the Christchurch earthquake (e.g., Bradley and

35 Cubrinovski, 2011; Bradley, 2012a,b,c; Shahi and Baker, 2012). The strike slip rupture mechanism of the

36 Darfield earthquake and the orientation of the causative fault relative to Christchurch resulted in the

37 manifestation of forward directivity effects throughout much of the city. In contrast, the predominantly

38 reverse rupture mechanism of the Christchurch earthquake and the causative fault orientation only

39 resulted in forward directivity effects in areas south of the city along the Port Hills. This allows a

40 comparison to be made between the spatial variation of MSF across the same region for motions where

41 directivity effects were and were not prominent.

43 In the following, background information on the geology and geomorphology of the Canterbury region is

44 presented. This is followed by a brief overview of the CES. Next, background information is given on the 45 approaches used to compute MSF. These approaches are then used to compute MSF across the 46 Christchurch region, with the trends in the results discussed.

\section{Background Information}

\section{$49 \quad 2.1$ Geology and Geomorphology of the Christchurch Area}

50 The Canterbury Plains are $\sim 160 \mathrm{~km}$ long and up to $60 \mathrm{~km}$ wide. The plains are the result of overlapping 51 alluvial fans produced by glacier-fed rivers from the Southern Alps, the main mountain range of the South 52 Island (Forsyth et al., 2008). Uplift of the Southern Alps resulted in rapid deposition during the late 
Quaternary and inundation of the Canterbury Plains by alluvial and fluvial sediments. The Canterbury

54 Plains are underlain by a deep and complex network of overlapping fingers of fluvial gravels interbedded with swamp, estuarine, lagoon, and beach deposits of sand, silt, clays, and peat as a result of the glacial and post-glacial movements of the coastline (Brown et al., 1995). Figure 2 shows an idealized cross section of the interbedded sedimentary deposits beneath the region. Also shown in this figure is the approximate depth to the uppermost gravel formation (i.e., Riccarton Gravel Formation) for several of the strong motion recording stations (SMSs) located in the Central Business District (CBD) and eastern suburbs of Christchurch (note that the simplified model of the depth to the Riccarton Gravel Formation shown in this figure is in accord with the 3D model of the formation developed by Lee et al. (2015)). The characterization of these SMS sites and several others are discussed later in the paper. was constructed on slightly higher ground compared to areas to the north and east. Of particular relevance to liquefaction susceptibility of the region are the locations of abandoned paleo-channels of the Waimakariri, Heathcote, and Avon Rivers, and former swamps. These areas are underlain by, and filled with, young loose sandy sediments, with shallow groundwater levels (from 1 to $5 \mathrm{~m}$ below ground surface), which are highly susceptible to liquefaction (e.g., Wotherspoon et al., 2012).

\subsection{Canterbury Earthquake Sequence (CES)}

The 2010-2011 CES started at 4:35 am on 4 September 2010 NZ Standard Time (16:35 3 September 2010 earthquake (Bradley et al., 2014). Although the earthquake caused major damage to the built environment and induced widespread liquefaction, there were no fatalities or major injuries. The CES included twelve 
other events having $\mathrm{M}_{\mathrm{w}} \geq 5.0$ with epicentral locations within $20 \mathrm{~km}$ of Christchurch (GeoNet, 2012), and up to ten of these larger events are known to have induced liquefaction (Quigley et al., 2013). However, the $\mathrm{M}_{\mathrm{w}} 6.2$, 22 February 2011 Christchurch earthquake was the most damaging event, due to the close proximity of its rupture plane to Christchurch, resulting in 185 fatalities and causing widespread liquefaction (e.g., Cubrinovski et al., 2011; Green et al., 2011; Orense et al., 2011; Cubrinovski et al., 2012; Robinson et al., 2013; Maurer et al., 2014).

85

The motions from both the Darfield and Christchurch earthquakes were recorded by a dense network of strong ground motion stations (e.g., Cousins and McVerry, 2010; Bradley and Cubrinovski, 2011; Bradley, 2012a,b,c; Bradley et al., 2014). The recordings included a significant number of near-fault motions, many of which show clear evidence of the forward directivity phenomenon (Bradley, 2012c; Bradley and Cubrinovski, 2011; Joshi, 2013). In an effort to better understand site effects in the ground

91 motions recorded across Christchurch, Wotherspoon et al. (2014, 2015a,b) performed a detailed characterization of the shallow $(\sim 40 \mathrm{~m})$ subsoil conditions at the 15 SMSs shown in Figure 3 . The profiles obtained by Wotherspoon et al. form the basis of the site response analyses performed herein.

\subsection{Magnitude Scaling Factors (MSF)}

96

As stated previously, magnitude scaling factors account for the influence of the durational effects of strong ground motion on liquefaction triggering. For historical reasons, MSF are normalized to $\mathrm{M}_{\mathrm{w}} 7.5$ events and traditionally have been computed from number of equivalent cycle correlations using the following relationship (e.g., Green, 2001; Boulanger and Idriss, 2015):

100

101

$$
M S F=\left(\frac{n_{e q} M 7.5}{n_{e q} M}\right)^{b}
$$


where $\mathrm{n}_{\mathrm{eqM} 7.5}$ and $\mathrm{n}_{\mathrm{eqM}}$ are the number of equivalent cycles for $\mathrm{M}_{\mathrm{w}} 7.5$ and $\mathrm{M}_{\mathrm{w}}$ events, and $b$ is the negative

104 slope of the $\log (\mathrm{CSR})$ versus $\log \left(\mathrm{N}_{\mathrm{liq}}\right)$ curve for the soil of interest; CSR is cyclic stress ratio (i.e., cyclic 105 shear stress $(\tau)$ divided by the initial vertical effective $\operatorname{stress}\left(\sigma^{\prime}{ }_{\text {vo }}\right)$ ), and $\mathrm{N}_{\text {liq }}$ is the number of cycles 106 required to trigger liquefaction in a soil specimen subjected to sinusoidal loading having an amplitude of 107 CSR, typically determined using cyclic triaxial or cyclic simple shear tests. Alternatively, MSF have been 108 developed directly from the statistical analysis of liquefaction case histories (e.g., Cetin et al., 2004). 109 However, this approach is limited by the relatively narrow variable ranges of the cases in the liquefaction 110 case history databases.

112 Well-established fatigue theories have been proposed for computing $\mathrm{n}_{\mathrm{eq}}$ for materials having varying 113 phenomenological behavior; reviews of different approaches for computing $\mathrm{n}_{\mathrm{eq}}$ are provided in Kaechele 114 (1963), Stallymeyer and Walker (1968), Green and Terri (2005), and Hancock and Bommer (2005), 115 among others. Developed specifically for use in evaluating liquefaction potential, the approaches 116 proposed by Seed et al. (1975) and by Green and Terri (2005) are used herein. These approaches are 117 variants of the Palmgren-Miner (P-M) fatigue theory, with the approach by Green and Terri (2005) better 118 accounting for the non-linear behavior of the soil than the Seed et al. (1975) variant.

120 Assuming that ground surface accelerations $(a)$ and corresponding shear stresses $(\tau)$ in the upper $\sim 6 \mathrm{~m}(20$

$121 \mathrm{ft}$ ) of a soil profile are proportional, the Seed et al. (1975) variant of the P-M fatigue theory can be 122 expressed as:

$$
n_{e q}=\sum_{i} 0.5 \cdot\left(\frac{1}{0.65} \cdot \frac{\left|a_{i}\right|}{a_{\max }}\right)^{\frac{1}{b}}
$$


126 where $\left|a_{i}\right|$ is the absolute value of the amplitude of the $\mathrm{i}^{\text {th }}$ peak (or pulse) in a horizontal acceleration time

127 history recorded at the ground surface, and $\mathrm{a}_{\max }$ is the peak ground acceleration for the same acceleration

128 time history; $b$ is as defined for Eq. 1. Inherent to the Seed et al. (1975) procedure, the ratio of

129 acceleration and peak ground acceleration $\left(a / a_{\max }\right)$ is assumed equal to $\tau / \tau_{\max }$, where $\tau_{\max }$ is the maximum 130 shear stress induced in the soil profile at the depth of interest.

132 There are several different "peak counting" methods (ASTM, 2011) that are used in fatigue analyses.

133 Seed et al. (1975) used a version of the mean crossing peak counting (also known as zero-crossing)

134 method wherein the amplitude of one cycle is taken as the maximum value of the response history

135 between successive zero crossings. Also, Seed et al. (1975) excluded peaks having amplitudes less than 136 approximately $0.3 \cdot \mathrm{a} / \mathrm{a}_{\max }$ in computing $\mathrm{n}_{\mathrm{eq}}$ because their contribution was considered to be negligible. To

137 calculate the equivalent number of cycles from two mutually perpendicular horizontal components of

138 motion, Seed et al. suggested two ways without giving a clear preference for one or the other: (1)

139 Normalize each component of motion by its own $\mathrm{a}_{\max }$; and (2) Normalize both components of motion by

140 the larger $\mathrm{a}_{\max }$ of the two motions. Although Seed et al. do not state a preference for one approach over

141 the other, approach (1) has been widely used in subsequent studies. Using this approach, Seed et al.

142 (1975) computed a mean value of $n_{\text {eqM7.5 }}=15$ from a suite of $\sim 60$ motions from earthquakes in the 143 western US and South America.

145 In the Green and Terri (2005) approach, dissipated energy is explicitly used as the damage metric. $\mathrm{n}_{\mathrm{eq}}$ is 146 determined by equating the energy dissipated in a soil element subjected to an earthquake motion to the 147 energy dissipated in the same soil element subjected to a sinusoidal motion of a given amplitude and a 148 duration of $\mathrm{n}_{\mathrm{eq}}$. Dissipated energy was selected as the damage metric because it has been shown to 149 correlate with excess pore pressure generation in saturated cohessionless soil samples subjected to 150 undrained cyclic loading (e.g., Green et al., 2000; Polito et al., 2008). Furthermore, from a microscopic 
perspective, energy is thought to be predominantly dissipated by the friction between sand grains as they move relative to each other as the soil skeleton breaks down, which is requisite for liquefaction triggering.

Conceptually, the Green and Terri (2005) approach for computing $\mathrm{n}_{\mathrm{eq}}$ is shown in Figure 4. Stress and strain time histories at various depths in the soil profile are obtained from a numerical site response analysis. By integrating the variation of shear stress over shear strain, the cumulative dissipated energy

157 per unit volume of soil can be computed (i.e., the cumulative area bounded by the stress-strain hysteresis 158 loops). $\mathrm{n}_{\mathrm{eq}}$ is then determined by dividing the cumulative dissipated energy for the entire earthquake 159 motion by the energy dissipated in one equivalent cycle. For historical reasons, the shear stress amplitude 160 of the equivalent cycle $\left(\tau_{\text {avg }}\right)$ is taken as 0.65 time the maximum induced shear stress $\left(\tau_{\max }\right)$ at the depth of 161 interest, and the dissipated energy associated with the equivalent cycle is determined from the constitutive 162 model used in the site response analysis. Additionally, the $b$ value that is needed to relate $\mathrm{n}_{\mathrm{eq}}$ to MSF per

163 Eq. 1 can also be determined from the constitutive model used in the site response analysis, by assuming 164 that the CSR vs. $\mathrm{N}_{\text {liq }}$ curve is a contour of constant dissipated energy (Lasley et al., 2016). Finally, from 165 equivalent linear site response analyses performed on 50 soil profiles compiled by Cetin (2000) that are 166 representative of cases in the liquefaction case history database, using 195 pairs of horizontal rock 167 motions recorded during 47 earthquakes as input motions, Lasley et al. (2016) determined the median $168 \quad \mathrm{n}_{\mathrm{eqM} 7.5}$ to be equal to 8.2 .

\section{Computation of MSF for the Darfield and Christchurch Earthquakes}

171 MSF were computed for both the Darfield and Christchurch earthquakes at the 15 SMS sites shown in 172 Figure 3 and listed in Table 1. These sites were selected because of the detailed site characterization 173 performed at them (Wotherspoon et al., 2014, 2015a,b). As described below, equivalent linear site 174 response analyses were performed to compute $\mathrm{n}_{\text {eq }}$ as a function of depth at each SMS site per the Green 175 and Terri (2005) procedure and from the computed surface acceleration time histories per the Seed et al. 176 (1975) procedure. Bedrock or the Riccarton Gravel Formation was assumed as the elastic half space in the 
177 equivalent linear site response analyses for these sites. For the cases where the Riccarton Gravel

178 Formation was assumed to be the elastic halfspace, this assumption is based on the sharp impedance

179 contrast between the Riccarton Gravel Formation and the looser overlying sediments (Brown and Weeber,

180 1992). For all the analyses, the input motions were input as rock-outcrop motions at the depth of the

181 elastic halfspace. Additional information on the SMS site profiles and the selection of the input motions

182 for the site response analyses are given in the following sections.

\subsection{SMS Profiles}

186 As stated above, detailed site characterization was performed at the 15 SMS sites listed in Table 1.

187 Methods used to characterize the site included active and passive-source surface wave testing, standard 188 penetration testing (SPT), cone penetration testing (CPT), and horizontal to vertical spectral ratio (H/V) 189 calculations. The shear wave velocity profiles for the 15 SMS sites used in the site response analyses were 190 developed from the combination of the active and passive-source surface wave techniques, and layering 191 constrained using subsurface investigation data. The idealized soil stratigraphy was inferred for each 192 profile using the collection of CPT soil behavior type indices, and SPT boreholes performed at each site.

193 Because the depth to bedrock at some of the SMS sites is $\sim 500 \mathrm{~m}$, detailed characterization down to 194 bedrock was only feasible for HVSC, where the depth to bedrock was only $19 \mathrm{~m}$. Twelve of the other 195 sites were characterized down to the Riccarton Gravel Formation (i.e., CACS, CBGS, CCCC, CHHC, 196 CMHS, KPOC, PPHS, PRPC, REHS, RHSC, SHLC, and SMTC); for all of these sites, the Riccarton 197 Gravel Formation is at a depth less than $30 \mathrm{~m}$. For the remaining two sites (i.e., HPSC and NNBS), the 198 depth to the Riccarton Gravel is greater than $30 \mathrm{~m}$ and the sites were only characterized down to $\sim 30 \mathrm{~m}$. 199 For these latter two sites, the small strain shear wave velocity (Vs) profiles were extrapolated to the 200 estimated depth of the Riccarton Gravel Formation using the relationship (Menq, 2003): 
204 where $A_{s}$ is the small strain shear wave velocity corresponding to an initial effective mean stress equal to

$2051 \operatorname{atm}\left(\mathrm{P}_{\mathrm{a}}\right), \mathrm{n}$ is a calibrated exponent of normalized effective mean stress, and $\sigma{ }_{0}$ is the mean effective 206 stress at the depth of the Riccarton Gravel Formation. The values of $\mathrm{A}_{\mathrm{s}}$ and $\mathrm{n}$ used to model dense gravel 207 were $312 \mathrm{~m} / \mathrm{s}$ and 0.331, respectively (Menq, 2003). Values of $\mathrm{V}_{\mathrm{s}}$ for the Riccarton Gravel Formation at 208 HPSC and NNBS SMS sites were calculated to be 400 and $415 \mathrm{~m} / \mathrm{s}$, respectively, which fall in the range 209 of $400-450 \mathrm{~m} / \mathrm{s}$ measured at the twelve sites noted above and listed in Table 1.

211 Figure 5 shows the profile for the North New Brighton School (NNBS) SMS site used in the equivalent 212 linear site response analyses, performed using ShakeVT2 (Lasley et al., 2014). The profiles for all 15 213 SMS sites are shown in Part A of the Electronic Supplement. The non-linear behavior of the soil was 214 assumed to follow the Darendeli and Stokoe (2001) shear modulus and damping degradation curves.

\subsection{Input Ground Motions}

217 An ensemble of site- and event-specific motion sets were selected for use in the site response analyses.

218 Towards this end, 15 sets of horizontal motions were selected for each SMS-earthquake scenario using 219 the generalized conditional intensity measure (GCIM) approach (Bradley 2010a, 2012d). The GCIM220 based ground motion selection process for a given scenario can be broken down into two main steps. The 221 first step entails the selection of motions that fall within a range of target causal parameters (e.g., $\mathbf{M}_{\mathrm{w}}$, $222 \mathrm{R}_{\mathrm{rup}}, \mathrm{V}_{\mathrm{s} 30}$, source mechanism, etc.). For this study, the following causal parameters and ranges were used: $223 \mathrm{M}_{\mathrm{w}} \pm 0.75$ magnitude units (i.e., $\mathrm{Mw}$ : 6.35-7.85 and 5.45-6.95 for the Darfield and Christchurch 224 earthquakes, respectively), $\mathrm{R}_{\mathrm{rup}}<75 \mathrm{~km}$, and $\mathrm{V}_{\mathrm{s} 30}>150 \mathrm{~m} / \mathrm{s}$. Additionally, to ensure the selected motions 225 were from shallow crustal events in active tectonic regions, analogous to the tectonic settings of the 226 Darfield and Christchurch events, motions were only selected from the NGA West ground motion 
database (Chiou et al., 2008), supplemented with "pulse-like" motions from the NGA West2 database (Seyhan et al., 2014) to ensure an adequate number of candidate motions with directivity effects.

The second step in the GCIM-based ground motion selection process entails the use of target distributions of intensity measures generated from ground motion predictive equations (GMPEs). To capture ground motion severity for a specific SMS-earthquake scenario, a multivariate distribution of intensity measures 233 (e.g., spectral acceleration, cumulative absolute velocity, Arias intensity, significant duration, etc.)

234 computed from GMPEs is used as the target. Each of the chosen intensity measures can be weighted 235 according to their deemed significance, and to optimize the fit of candidate motions to the target 236 distributions, scale factors can be applied to the amplitude of the motions.

For this study, spectral acceleration (SA), cumulative absolute velocity (CAV), Arias intensity $\left(\mathrm{I}_{\mathrm{a}}\right)$, and 5$75 \%$ and $5-95 \%$ significant durations $\left(\mathrm{D}_{\mathrm{s} 575}\right.$ and $\mathrm{D}_{\mathrm{s} 595}$, respectively) were chosen as the target intensity measures. These intensity measures were chosen because each is considered to influence liquefaction triggering (e.g., Kramer and Mitchell, 2006). Listings of the GMPEs used to compute the respective target distributions of intensity measures and the weights assigned to each intensity measure are given in Table 2 (Tarbali and Bradley, 2014). The target distributions of the intensity measures were computed for each

244 SMS site using the small strain shear wave velocity for the assumed elastic half space, listed in Table 1.

245 The target SA for a damping ratio of $5 \%$ was defined at 21 oscillator periods: $\mathrm{T}=0.05,0.075,0.1,0.15$, $2460.2,0.25,0.3,0.4,0.5,0.75,1.0,1.5,2.0,2.5,3.0,3.5,4.0,4.5,5.0,7.5$, and $10.0 \mathrm{~s}$. For the scenarios 247 where forward directivity was considered (Joshi, 2013), the spectral accelerations were amplified at the 248 pulse period $\left(\mathrm{T}_{\mathrm{p}}\right)$ determined from the actual recorded motions at the site using the Shahi and Baker 249 (2011) narrowband model. Scale factors ranging from 0.5 to 2 were applied to the amplitude of the 250 motions to optimize the fit of the motions to the target distributions. In total, 15 sets of horizontal motions 251 were selected for each SMS-earthquake pair, resulting in a total of 900 motions selected (2 motions per 252 horizontal set $\times 15$ sets of motions per SMS-earthquake scenario $\times 15$ SMS $\times 2$ earthquakes $=900$ 
motions). The sets of ground motions selected for the NNBS SMS site for both the Darfield and

254 Christchurch earthquakes using the GCIM-based process are discussed in the following.

255

Figure 6 shows the $M_{w}$ vs. $R_{\text {rup }}$ distributions of selected ground motions for the NNBS SMS site for both the Darfield and Christchurch earthquakes. As expected, based on the adopted causal parameter bounds, it can be seen that the selected ground motions have magnitude and distance values that are relatively consistent with the 'target' values for the considered events (albeit the source-to-site distances for the Christchurch earthquake scenario are larger than the target due to the paucity of as-recorded motions for $<5 \mathrm{~km}$ distances). Figure 7 shows the median and the $16^{\text {th }}$ and $84^{\text {th }}$ percentiles of the $5 \%$ damped target response spectrum. For comparison, the response spectra for the selected motions are also shown, along with the median and the $16^{\text {th }}$ and $84^{\text {th }}$ percentiles for the selected motions. As may be observed, the distributions of SA fit the target distributions reasonably well for both earthquakes, albeit more so for the Christchurch earthquake which does not include the pronounced long-period forward directivity spectral peak. Figure 8 shows the target distributions for the other intensity measures chosen, along with those for the selected motions. For these other intensity measures, the selected motions appropriately represent the target distribution.

\section{Results and Discussion}

Using the Seed et al. (1975) and Green and Terri (2005) approaches for computing $\mathrm{n}_{\text {equ }}$ in conjunction with the results from the site response analyses performed as described above, MSF were computed per Eq. 1 for each of the 15 SMS sites for both the Darfield and Christchurch earthquakes. In computing $\mathrm{n}_{\text {eqM }}$ per the Seed et al. (1975) procedure (i.e., per Eq. 2) and in computing the MSF for using the $\mathrm{n}_{\text {eqM }}$ from both the Seed et al. (1975) and Green and Terri (2005) (i.e., per Eq. 1), $b$ was assumed to equal 0.34. As shown in Lasley et al. (2016), this value is consistent with the Darendeli and Stokoe (2001) shear modulus and damping degradation curves for a range of densities and effective confining stresses, based on the assumption that a CSR vs. $\mathrm{N}_{\text {liq }}$ curve is a contour of constant dissipated energy. This assumption 
has been shown to be reasonably in accord with laboratory data (e.g., Kokusho and Kaneko, 2014; Polito et al., 2013). Additionally, $b=0.34$ is consistent with laboratory curves developed from high-quality undisturbed samples obtained by freezing (Yoshimi et al., 1984).

The MSFs for the NNBS SMS site are shown in Figure 9 and those for all 15 SMS sites are shown in Part

284 B of the Electronic Supplement. A few trends may be observed from this figure. First, the MSF for the

285 Darfield earthquake are generally less than those for the Christchurch earthquake, which is expected

286 because the magnitude for the Darfield earthquake is larger than that for the Christchurch earthquake (i.e.,

$287 M_{w} 7.1$ vs. $M_{w} 6.2$ ). Second, the MSF computed using the $n_{\text {eqM }}$ from the Green and Terri (2005) approach

288 is relatively constant with depth, although the standard deviation decreases slightly with depth; this trend

289 was also identified by Lasley et al. (2016) (Note that the MSF computed using the $\mathrm{n}_{\text {eqM }}$ from the Seed et

290 al. (1975) approach are computed using surface ground motions; hence, the corresponding MSFs and

291 standard deviations are assumed constant with depth). Third, the MSFs computed using the $\mathrm{n}_{\text {eqM }}$ from the

292 Seed et al. (1975) approach are larger than those computed using the $\mathrm{n}_{\mathrm{eqM}}$ computed using the Green and

293 Terri (2005) approach. This actually has more to do with the values used for $\mathrm{n}_{\text {eqM7.5 }}$ (i.e., 15 for the Seed

294 et al. approach versus 8.2 for the Green and Terri approach) rather than with the computed values for

$295 \mathrm{n}_{\mathrm{eqM}}$, which were very similar for both approaches. However, the focus of this study is on the spatial

296 variation of MSF during the Darfield and Christchurch earthquakes, not on the absolute values of the

297 MSF at any given site. Similarly, it should be noted that the MSF computed herein (either those computed

298 using the $\mathrm{n}_{\text {eqM }}$ from the Seed et al. (1975) or the Green and Terri (2005) approaches) should not be used in

299 conjunction with any of the existing simplified liquefaction evaluation procedures. Rather, the MSF

300 recommended by a given procedure should be used with that procedure.

302 Contour plots of MSF computed using the $\mathrm{n}_{\text {eqM }}$ from the Green and Terri (2005) approach for both the 303 Darfield and Christchurch earthquakes are shown in Figure 10; similar plots for MSF computed using $304 \mathrm{n}_{\mathrm{eqM}}$ from the Seed et al. (1975) approach are shown in Part C of the Electronic Supplement. As may be 
observed, similar trends are shown in contour plots of the MSF computed using the Green and Terri

306 (2005) and the Seed et al. (1975) approaches. These contours are superimposed on maps of the

307 Christchurch region, with areas that experienced liquefaction also shown. Because the MSF computed

308 using the $\mathrm{n}_{\text {eqM }}$ from the Green and Terri (2005) approach vary to some extent with depth, the contour plots

309 are developed from the MSF computed at the "critical" depths for each of the SMSs, where critical depth

310 is assumed herein to be that to the layer most susceptible to liquefaction (i.e., depth to the layer having the

311 lowest computed factor of safety against liquefaction). For SMSs sites where no layers were deemed

312 susceptible to liquefaction, the critical depth was taken as $\sim 4.75 \mathrm{~m}$ which corresponds to the median

313 critical depth of compiled liquefaction case histories (e.g., Cetin et al., 2004; Boulanger and Idriss, 2014).

314 Both the depths to the layer having the lowest factor of safety against liquefaction and to an initial vertical

315 effective stress of 1 atm are identified in Figure 9 for the NNBS SMS site and are tabulated in Table 3 for 316 all sites.

As may be observed from Figure 10, the MSF for the Darfield and Christchurch earthquakes range from approximately 0.9 to 1.2 and from approximately 0.95 to 1.46 , respectively, with a general trend of MSF being higher in the southern part of the Christchurch and increasing in a northerly direction. However, 321 despite these ranges in MSF being relatively significant, particularly for the Christchurch earthquake, 322 there does not appear to be a consistent correlation between lower computed MSF and observed 323 liquefaction. For example, widespread liquefaction was observed in Kaiapoi during the Darfield 324 earthquake, which is an area having a relatively low MSF ( 0.9). However, Kaiapoi did not experience as 325 severe or as widespread liquefaction during the Christchurch earthquake, but the MSF for this area for 326 this event are also relatively low ( 0.95). More significantly, portions of the CBD and eastern 327 Christchurch experienced severe and widespread liquefaction during the Christchurch earthquake, yet 328 relatively high MSF are computed for these regions for this event. However, it should be realized that the 329 seismic demand imposed on the soil is both a function of the amplitude and the duration of the motions, 330 where the former is proportional to $\mathrm{a}_{\max }$. Additionally, the capacity of the soil to resist liquefaction varies 
331 spatially, which inherently influenced the liquefaction response observed during the Darfield and

332 Christchurch earthquakes.

334 In comparing contour maps of the median $\mathrm{a}_{\max }$ values from the site response analyses (Figure 11) with the 335 contour maps for MSFs (Figure 10), it is observed that there is a general correlation between MSF and $336 a_{\max }$ (i.e., regions having higher $\mathrm{a}_{\max }$ values also have higher MSFs). This results in opposing effects on 337 the seismic demand imposed in the soil (i.e., higher $\mathrm{a}_{\max }$ induces higher seismic demand in the soil, while

338 a higher MSF results in a lower seismic demand). However, of the two parameters, $a_{\max }$ ranges more 339 widely than MSF and thus has a greater influence on the resulting seismic demand imposed on the soil. 340 Nevertheless, the spatial variation of the MSF is significant enough that it could potentially contribute to 341 discrepancies between predicted versus observed liquefaction.

\section{5. Summary and Conclusions}

344 MSF account for the durational effects of strong ground shaking on liquefaction triggering within the 345 simplified liquefaction evaluation procedure, and it has traditionally been assumed that they are only a 346 function of earthquake magnitude. However, this assumption fails to appreciate the inverse correlation 347 between the peak amplitude of ground motions and strong ground motion duration, and thus would 348 seemingly vary spatially (e.g., distance from source). The combination of well-documented liquefaction 349 response during the Darfield and Christchurch, New Zealand, earthquakes, densely-recorded ground 350 motions for the events, and detailed subsurface characterization provides an unprecedented opportunity to 351 investigate the significance of the spatial variation of MSF on liquefaction triggering. Towards this end, 352 MSF were computed at 15 SMS sites across Christchurch and its environs using $\mathrm{n}_{\text {eqM }}$ computed using the 353 approaches proposed by Seed et al. (1975) and by Green and Terri (2005). Both of these approaches are 354 inherently "total stress" approaches (i.e., no consideration is given to influence of excess pore water 355 pressure on soil stiffness), consistent with the total stress-based simplified liquefaction evaluation 356 procedure framework. 
358 Trends in the spatial variation of the MSF computed using $\mathrm{n}_{\mathrm{eqM}}$ from both the Seed et al. (1975) and

359 Green and Terri (2005) approaches were similar, and the MSF computed using the $\mathrm{n}_{\text {eqM }}$ from the Green 360 and Terri (2005) approach ranged from 0.9 to 1.2 and from 0.95 to 1.46 across Christchurch for the 361 Darfield and Christchurch earthquakes, respectively. Note that the impact of the spatially varying MSF on 362 the computed factor of safety against liquefaction would more directly indicate the significance of the 363 results presented herein. However, the absence of a cyclic resistance ratio (CRR) curve developed from 364 liquefaction field case histories analyzed using a spatially varying MSF precludes this at present.

366 From examining the spatial variation of the MSF across Christchurch, there was no consistent trend for 367 regions with lower computed MSF having experienced more severe or widespread liquefaction. However, 368 it was observed that there is a general correlation between MSF and $a_{\max }$ (i.e., regions having higher $\mathrm{a}_{\max }$ 369 values also have higher MSFs), but $\mathrm{a}_{\max }$ ranges more widely than MSF and thus has a greater influence on 370 the resulting seismic demand imposed on the soil. Nevertheless, the spatial variation of the MSF is 371 deemed significant enough that it could result in discrepancies between predicted versus observed 372 liquefaction and thus warrants consideration for incorporation in future variants of simplified liquefaction 373 evaluation procedures.

\section{6. Acknowledgments}

376 This research was partially funded by National Science Foundation (NSF) grants CMMI-1030564, 377 CMMI-1407428, and CMMI-1435494. Drs. Sam Lasley and Brett Maurer assisted in some of the 378 calculations presented herein. Additionally, Mr. Karim Tarbali and Mr. Varun Joshi assisted with the 379 near-fault ground motion selection process. This support and assistance are gratefully acknowledged. 380 However, any opinions, findings, and conclusions or recommendations expressed in this material are 381 those of the authors and do not necessarily reflect the views of the National Science Foundation. 


\section{References}

Archuleta, R.J. and Hartzell, S.H. (1981). "Effects of fault finiteness on near-source ground motion." Bulletin of the Seismological Society of America, 71, 939-957.

ASTM (2011). "Practices for Cycle Counting in Fatigue Analysis.” ASTM Standard E1049, 1985, ASTM International, West Conshohocken, PA, www.astm.org

Beavan, J., Fielding,, E., Motagh, M., Samsonov, S., and Donnelly, N. (2011). "Fault Location and Slip Distribution of the 22 February $2011 \mathrm{Mw}$ 6.2 Christchurch, New Zealand, Earthquake from Geodetic Data." Seismological Research Letters, 82(6), 789-799.

Bommer, J.J., and Martinez-Pereira, A. (1999). "The effective duration of earthquake strong motion." Journal of Earthquake Engineering, 3(2), 127-172.

Bommer, J.J., Stafford, P.J., and Alarcón, J.E. (2009). "Empirical equations for the prediction of the significant, bracketed, and uniform duration of earthquake ground motion." Bulletin of the Seismological Society of America, 99(6), 3217-3233.

Boulanger, R.W., and Idriss, I.M. (2014). "CPT and SPT based liquefaction triggering procedures." Report No. UCD/CGM-14/01, Center for Geotechnical Modeling, Department of Civil and Environmental Engineering, University of California, Davis, CA, 134 pp.

Boulanger, R.W. and Idriss, I.M. (2015). "Magnitude scaling factors in liquefaction triggering procedures.” Soil Dynamics and Earthquake Engineering, 79(Part B), 296-303.

Bradley, B.A. (2010a). "A generalized conditional intensity measure approach and holistic ground-motion selection.” Earthquake Engineering and Structural Dynamics, 39(12), 1321-1342.

Bradley, B.A. (2010b). "Site-specific and spatially distributed ground-motion prediction of acceleration spectrum intensity." Bulletin of the Seismological Society of America, 100(2), 792-801.

Bradley, B.A. and Cubrinovski, M. (2011). "Near-Source Strong Ground Motions Observed in the 22 February 2011 Christchurch Earthquake." Bulletin of the New Zealand Society for Earthquake Engineering, 44(4):181-194.

Bradley, B.A. (2012a). “A ground motion selection algorithm based on the generalized conditional intensity measure approach.” Soil Dynamics and Earthquake Engineering, 40, 48-61.

Bradley, B.A. (2012b). "Observed Ground Motions in the 4 September 2010 Darfield and 22 February 2011 Christchurch Earthquakes.” Proc. 2012 NZSEE Conference, 13-15 Apr 2012, Paper 037. 
Bradley, B.A. (2012c). "Ground motions observed in the Darfield and Christchurch earthquakes and the importance of local site response effects." New Zealand Journal of Geology and Geophysics, 55(3), 279-286.

Bradley, B.A. (2012d). "Strong ground motion characteristics observed in the 4 September 2010 Darfield, New Zealand earthquake." Soil Dynamics and Earthquake Engineering, 42, 32-46.

Bradley, B.A. (2013a). Ground motion selection for seismic risk analysis of civil infrastructures. Handbook of seismic risk analysis and management of civil infrastructure systems (S. Tasfamariam and K. Goda, eds.), Woodhead Publishing Ltd.

Bradley, B.A. (2013b). “A New Zealand-Specific Pseudospectral Acceleration Ground-Motion Prediction Equation for Active Shallow Crustal Earthquakes Based on Foreign Models." Bulletin of the Seismological Society of America, 103(3), 1801-1822.

Bradley, B.A., Quigley, M.C., Van Dissen, R.J., and Litchfield, N.J. (2014). "Ground motion and seismic source aspects of the Canterbury earthquake sequence.” Earthquake Spectra, 30(1), 1-15.

Brown, L.J., Beetham, R.D., Paterson, B.R., and Weeber, J.H. (1995). "Geology of Christchurch, New Zealand," Environmental \& Engineering Geoscience, 1(4), 427-488.

Brown, L.J. and Weeber, J.H. (1992). "Geology of the Christchurch urban area.” Geological and Nuclear Sciences (GNS Science), 110pp.

Campbell, K.W. and Bozorgnia, Y. (2010). "A ground motion prediction equation for the horizontal component of cumulative absolute velocity (CAV) based on the PEER NGA strong motion database." Earthquake Spectra, 26(3), 635-650.

Campbell, K.W. and Bozorgnia, Y. (2012). "A comparison of ground motion prediction equations for Arias intensity and cumulative absolute velocity developed using a consistent database and functional form." Earthquake Spectra, 28(3), 931-941.

Cetin, K.O. (2000). "Reliability-based assessment of seismic soil liquefaction initiation hazard." Ph.D. Thesis, University of California at Berkeley, Berkeley, CA.

Cetin, K.O., Seed, R.B., Der Kiureghian, A., Tokimatsu, K., Harder, Jr., L.F., Kayen, R.E., and Moss, R.E.S. (2004). "Standard Penetration Test-Based Probabilistic and Deterministic Assessment of Seismic Soil Liquefaction Potential." Journal of Geotechnical and Geoenvironmental Engineering, 130(12), 1314-1340.

Chiou, B., Darragh, R., Gregor, N., and Silva, W. (2008). "NGA Project Strong-Motion Database." Earthquake Spectra, 24(1), 23-44. 
Cousins, J. and McVerry, G.H. (2010). "Overview of strong motion data from the Darfield earthquake." Bulletin of the New Zealand Society for Earthquake Engineering, 43(4), 222-227.

Cubrinovski, M. and Green, R.A., eds., (2010). "Geotechnical Reconnaissance of the 2010 Darfield (Canterbury) Earthquake." (contributing authors in alphabetical order: J. Allen, S. Ashford, E. Bowman, B. Bradley, B. Cox, M. Cubrinovski, R. Green, T. Hutchinson, E. Kavazanjian, R. Orense, M. Pender, M. Quigley, and L. Wotherspoon), Bulletin of the New Zealand Society for Earthquake Engineering, 43(4), 243-320.

Cubrinovski, M., Bradley, B., Wotherspoon, L., Green, R., Bray, J., Woods, C., Pender, M., Allen, J., Bradshaw, A., Rix, G., Taylor, M., Robinson, K., Henderson, D., Giorgini, S., Ma, K., Winkley, A., Zupan, J., O'Rourke, T., DePascale, G., and Wells, D. (2011). "Geotechnical aspects of the 22 February 2011 Christchurch earthquake." Bulletin of the New Zealand Society for Earthquake Engineering, 43(4), 205-226.

Darendeli, M.B. and Stokoe II, K.H. (2001). "Development of a new family of normalized modulus reduction and material damping curves." Geotechnical Engineering Report GD01-1, University of Texas at Austin.

Forsyth, P.J., Barrell, D.J.A., and Jongens, R. (compilers) (2008). "Geology of the Christchurch area," Geological \& Nuclear Sciences 1:250000 Geological Map, 16. Lower Hutt, New Zealand. GNS Science.

Green, R.A. (2001). "Energy-Based Evaluation and Remediation of Liquefiable Soils.” Ph.D. Dissertation (J.K. Mitchell, Advisor), Department of Civil and Environmental Engineering, Virginia Polytechnic Institute and State University (Virginia Tech), Blacksburg, VA, 397pp.

Green, R.A., Mitchell, J.K., and Polito, C.P. (2000). "An Energy-Based Excess Pore Pressure Generation Model for Cohesionless Soils." Proc. The John Booker Memorial Symposium - Developments in Theoretical Geomechanics (D.W. Smith and J.P. Carter, eds.), A.A. Balkema, Rotterdam, The Neatherlands, 383-390.

Green, R.A. and Terri, G.A. (2005). "Number of Equivalent Cycles Concept for Liquefaction Evaluations - Revisited." Journal of Geotechnical and Geoenvironmental Engineering, ASCE, 131(4), 477-488.

Green, R.A., Cubrinovski, M., Cox, B., Wood, C., Wotherspoon, L., Bradley, B., and Maurer, B. (2014). "Select Liquefaction Case Histories from the 2010-2011 Canterbury Earthquake Sequence." Earthquake Spectra, 30(1), 131-153. 
Hancock, J. and Bommer J.J. (2005). "The effective number of cycles of earthquake ground motion." Earthquake Engineering and Structural Dynamics, 34, 637-664.

Holden, C., Beavan, R.J., Fry, B., Reyners, M.E., Ristau, J., Van Dissen, R.J., Villamor, P., and Quigley, M. (2011). "Preliminary source model of the Mw 7.1 Darfield earthquake from geological, geodetic and seismic data." Proc. Ninth Pacific Conference on Earthquake Engineering (9PCEE): building an earthquake resilient society, April 14-16, 2011, University of Auckland, Auckland, New Zealand. Auckland, NZ, Paper No. 164.

Idriss, I.M. and Boulanger, R.W. (2008). Soil Liquefaction during Earthquakes, Monograph MNO-12, Earthquake Engineering Research Institute, Oakland, CA, 261 pp.

Joshi VA. (2013). Near-fault forward directivity aspects of strong ground motions in the 2010-11 Canterbury earthquakes. Master of Engineering Thesis. November 2013. Christchurch, New Zealand. $354 \mathrm{pp}$.

Kaechele, L. (1963). "Review and analysis of cumulative-fatigue-damage theories." Memorandum RM3650-PR, The Rand Corporation, 1700 Main St., Santa Monica, CA.

Kramer, S.L. and Mitchell, R.A. (2006). "Ground Motion Intensity Measures for Liquefaction Hazard Evaluation.” Earthquake Spectra, 22(2), 413-438.

Kempton, J.J. and Stewart, J.P. (2006). "Prediction equations for significant duration of earthquake ground motions considering site and near-source effects." Earthquake Spectra, 22(4), 985-1013.

Kokusho, T. and Kaneko, Y. (2014). "Dissipated \& strain energies in undrained cyclic loading tests for liquefaction potential evaluations." Proc. 10th U.S. National Conf. on Earthquake Engineering, Earthquake Engineering Research Institute, Anchorage, AK.

Lasley, S.J., Green, R.A., and Rodriguez-Marek, A. (2014). "Comparison of equivalent-linear site response analysis software.” Proc. 10th U.S. National Conf. on Earthquake Engineering, Earthquake Engineering Research Institute, Anchorage, AK.

Lasley, S., Green, R.A., and Rodriguez-Marek, A. (2016). "Number of Equivalent Stress Cycles for Liquefaction Evaluations in Active Tectonic and Stable Continental Regimes," Journal of Geotechnical and Geoenvironmental Engineering, ASCE. (in press).

Lee, R.L., Bradley, B.A., Ghisetti, F., Thomson, E.M., Pettinga, J.R., and Hughes, M.W. (2015). “A geology-based 3D seismic velocity model of Canterbury, New Zealand.” Proc. New Zealand Society for Earthquake Engineering (NZSEE) Annual Conference, Paper Number O-63. 
Lee, J. and Green, R.A. (2014). “An Empirical Significant Duration Relationship for Stable Continental Regions." Bulletin of Earthquake Engineering, 12(1), 217-235.

Maurer, B., Green, R., Cubrinovski, M., and Bradley, B.A. (2014). "Evaluation of Liquefaction Potential Index for Assessing Liquefaction Hazard: A Case Study in Christchurch, New Zealand.” Journal of Geotechnical and Geoenvironmental Engineering, 140(7), 04014032.

Menq, F.-Y. (2003), “Dynamic Properties of Sandy and Gravely Soils,” Ph.D. Dissertation, The University of Texas at Austin, 390 pp.

Miner, M.A. (1945). “Cumulative damage in fatigue.” Journal of Applied Mechanics, 12(3), A159-A164.

Palmgren, A. (1924). "Die lebensdauer von kugellagern (Life length of roller bearings, in German)." Zeitschrift des Vereins Deutscher Ingenieure, 68(14), 339-341.

Polito, C., Green, R.A., Dillon, E., and Sohn, C. (2013). "The effect of load shape on the relationship between dissipated energy and residual excess pore pressure generation in cyclic triaxial tests." Canadian Geotechnical Journal, 50(9), 1118-1128.

Quigley, M.C., Bastin, S., and Bradley, B.A. (2013). "Recurrent liquefaction in Christchurch, New Zealand, during the Canterbury earthquake sequence." Geology, 41(4), 419-422.

Robinson, K., Cubrinovski, M., and Bradley, B.A. (2013). "Sensitivity of predicted liquefaction-induced lateral displacements from the 2010 Darfield and 2011 Christchurch earthquakes." Proc. 19th New Zealand Geotechnical Society (NZGS) Symposium, Queenstown, New Zealand, 20-23 Nov 2013.

Seed, H.B. and Idriss, I.M. (1971). "Simplified procedure for evaluating soil liquefaction potential." Journal of the Soil Mechanics and Foundations Division, 97(9), 1249-1273.

Seed, H.B., Idriss, I.M., Makdisi, F., and Banerjee, N. (1975). "Representation of irregular stress time histories by equivalent uniform stress series in liquefaction analyses, EERC 75-29." Earthquake Engineering Research Center, University of California, Berkeley.

Seyhan, E., Stewart, J.P., Ancheta, T.D., Darragh, R.B., and Graves, R.W. (2014). "NGA-West2 Site Database." Earthquake Spectra, 30(3), 1007-1024.

Shahi, S. K. (2013, January). A probabilistic framework to include the effects of near-fault directivity in seismic hazard assessment. Stanford University, Stanford.

Shahi, S.K. and Baker, J.W. (2011). "An empirically calibrated framework for including the effects of near-fault directivity in probabilistic seismic hazard analysis." Bulletin of the Seismological Society of America, 101(2), 742-755. 
Shahi, S.K. and Baker, J. W. (2013). NGA-West2 Models for Ground-Motion Directionality. Pacific Earthquake Engineering Research Center.

Somerville, P.G., Smith, N.F., Graves, R.W., and Abrahamson, N.A. (1997). "Modification of empirical strong ground motion attenuation relations to include the amplitude and duration effects of rupture directivity." Seismological Research Letters, 68, 199-222.

Stafford, P.J., Alarcon, J.E., and Bommer, J.J. (2009). "Empirical equations for the prediction of the equivalent number of cycles of earthquake ground motion." Soil Dynamics and Earthquake Engineering, 29(11-12), 1425-1436.

Stallmeyer, J.E. and Walker, W.H. (1968). "Cumulative damage theories and application.” Journal of the Structural Division, 94, 2739-2750.

Tarbali, K. and Bradley, B.A. (2014). "Scenario-based ground-motion selection using the generalized conditional intensity measure (GCIM) approach." Proc. 10 $0^{\text {th }}$ National Conf. on Earthquake Engineering (10NCEE), Anchorage, AK, 21-25 July.

Tarbali, K. and Bradley, B.A. (2014). "Representative ground motion ensembles for several major earthquake scenarios in New Zealand." Bulletin of the New Zealand Society of Earthquake Engineering, 47(4), 231-252.

Whitman, R.V. (1971). "Resistance of Soil to Liquefaction and Settlement." Soils and Foundations, 11(4), 59-68.

Wotherspoon, L.M., Pender, M.J., and Orense, R.P. (2012). "Relationship between observed liquefaction at Kaiapoi following the 2010 Darfield earthquake and former channels of the Waimakariri River." Engineering Geology, 125, 45-55.

Wotherspoon, L., Orense, R., Bradley, B.A., Cox, B., Green, R.A., and Wood, C. (2014). "Soil Profile Characterization of Christchurch Strong Motion Stations." Proc. $10^{\text {th }}$ National Conf. on Earthquake Engineering (10NCEE), Anchorage, AK, 21-25 July.

Wotherspoon, L.M., Orense, R.P., Bradley, B.A., Cox, B.R., Wood, C.M., and Green, R.A. (2015a). "Soil Profile Characterization of Christchurch Central Business District Strong Motion Stations," Bulletin of the New Zealand Society for Earthquake Engineering, 48(3), 147-157.

Wotherspoon, L., Orense, R., Bradley, B., Cox, B., Wood, C., and Green, R.A. (2015b). "Geotechnical Characterisation of Christchurch Strong Motion Stations," Version 3, Earthquake Commission Report (Project No. 12/629), Earthquake Commission (EQC), Wellington, New Zealand. 
562 Yoshimi, Y., Tokimatsu, K., Kaneko, O., and Makihara, Y. (1984). "Undrained cyclic shear strength of a 563 dense Niigata sand." Soils and Foundations, 24(4), 131-145.

564 Youd, T.L., Idriss, I.M., Andrus, R.D., Arango, I., Castro, G., Christian, J.T., Dobry, R., Finn, W.D.L., 565 Harder, L.F., Hynes, M.E., Ishihara, K., Koester, J.P., Liao, S.S.C., Marcuson III, W.F., Martin, G.R., 566 Mitchell, J.K., Moriwaki, Y., Power, M.S., Robertson, P.K., Seed, R.B., and Stokoe II, K.H. (2001). 567 "Liquefaction Resistance of Soils: Summary Report from the 1996 NCEER and 1998 NCEER/NSF 568 Workshops on Evaluation of Liquefaction Resistance of Soils." Journal of Geotechnical and 569 Geoenvironmental Engineering, 127(10), 817-833.

570

571 
Table 1. Strong motion station details.

\begin{tabular}{|l|c|c|c|c|c|c|c|}
\hline \multicolumn{1}{|c|}{ Station Name } & Code & Network & Latitude & Longitude & $\begin{array}{c}\mathrm{V}_{\mathrm{s}}^{*} \\
(\mathrm{~m} / \mathrm{s})\end{array}$ & $\begin{array}{c}\text { Dar } \\
\text { eqk }\end{array}$ & $\begin{array}{c}\text { Chch } \\
\text { eqk }\end{array}$ \\
\hline $\begin{array}{l}\text { Canterbury Aero } \\
\text { Club }\end{array}$ & CACS & NSMN & -43.48316539 & 172.5300139 & 600 & 11.9 & 12.9 \\
\hline $\begin{array}{l}\text { Christchurch Botanic } \\
\text { Gardens }\end{array}$ & CBGS & NSMN & -43.52933938 & 172.6198776 & 400 & 14.4 & 4.8 \\
\hline $\begin{array}{l}\text { Christchurch } \\
\text { Cathedral College }\end{array}$ & CCCC & CanNet & -43.5380850 & 172.6474270 & 400 & 16.3 & 2.9 \\
\hline Christchurch Hospital & CHHC & CanNet & -43.53592591 & 172.6275195 & 400 & 14.8 & 3.9 \\
\hline $\begin{array}{l}\text { Cashmere High } \\
\text { School }\end{array}$ & CMHS & NSMN & -43.56561744 & 172.6241694 & 400 & 14.0 & 1.5 \\
\hline $\begin{array}{l}\text { Hulverstone Dr } \\
\text { Pumping Station }\end{array}$ & HPSC & CanNet & -43.50157144 & 172.7021909 & 400 & 21.7 & 4.1 \\
\hline $\begin{array}{l}\text { Heathcote Valley } \\
\text { School }\end{array}$ & HVSC & CanNet & -43.57977835 & 172.7094230 & 760 & 20.8 & 3.9 \\
\hline Kaipoi North School & KPOC & CanNet & -43.37646016 & 172.6637603 & 450 & 27.7 & 17.5 \\
\hline $\begin{array}{l}\text { North New Brighton } \\
\text { School }\end{array}$ & NNBS & NSMN & -43.49541878 & 172.7179969 & 415 & 23.2 & 4.0 \\
\hline Papanui High School & PPHS & NSMN & -43.49284238 & 172.6069135 & 400 & 15.4 & 8.8 \\
\hline $\begin{array}{l}\text { Pages Rd Pumping } \\
\text { Station }\end{array}$ & PRPC & CanNet & -43.52580347 & 172.6827633 & 400 & 19.4 & 2.6 \\
\hline $\begin{array}{l}\text { Christchurch } \\
\text { Resthaven }\end{array}$ & REHS & NSMN & -43.52194513 & 172.6351501 & 400 & 15.9 & 4.9 \\
\hline $\begin{array}{l}\text { Riccarton High } \\
\text { School }\end{array}$ & RHSC & CanNet & -43.5361720 & 172.5644040 & 450 & 10.0 & 6.6 \\
\hline Shirley Library & SHLC & CanNet & -43.50533475 & 172.6633938 & 400 & 18.7 & 5.3 \\
\hline $\begin{array}{l}\text { Styx Mill Transfer } \\
\text { Station }\end{array}$ & SMTC & CanNet & -43.46752930 & 172.6138611 & 400 & 17.6 & 10.9 \\
\hline
\end{tabular}

$573 *$ The listed Vs are for the elastic halfspace assumed in the equivalent linear site response analyses, which 574 corresponded to the Riccarton Gravel Formation of all sites except HVSC, where the listed value is for 575 the Banks Peninsula volcanic rock. 
Table 2. Summary of intensity measures and weighting scheme used in GCIM ground motion selection

\begin{tabular}{|c|c|c|}
\hline Intensity Measure & GMPE & Weight \\
\hline Spectral Acceleration (SA) & Bradley (2013b) & $60 \% *$ \\
\hline $\begin{array}{c}\text { Cumulative Absolute Velocity } \\
(\mathrm{CAV})\end{array}$ & Campbell and Bozorgnia (2010) & $10 \%$ \\
\hline Arias Intensity ( $\left.\mathrm{I}_{\mathrm{a}}\right)$ & Campbell and Bozorgnia (2012) & $10 \%$ \\
\hline $\begin{array}{c}5-75 \% \text { Significant Duration } \\
\left(\mathrm{D}_{\mathrm{s} 575}\right)\end{array}$ & Bommer et al. (2009) & $10 \%$ \\
\hline $\begin{array}{c}5-95 \% \text { Significant Duration } \\
\left(\mathrm{D}_{\mathrm{s} 595}\right)\end{array}$ & Bommer et al. (2009) & $10 \%$ \\
\hline
\end{tabular}

581

582

583

584

585

586

$*$ Evenly distributed to $21 \mathrm{SA}$ ordinates (i.e. $60 \% / 21 \approx 2.86 \%$ per SA ordinate)

\begin{tabular}{|c|c|c|c|c|c|c|c|c|c|c|c|c|}
\hline \multirow{3}{*}{ Station } & \multicolumn{2}{|c|}{$\begin{array}{c}\mathrm{a}_{\max }(\mathrm{g}) \\
(\text { Surface })\end{array}$} & \multirow{3}{*}{$\begin{array}{c}\sigma_{\text {vo }}^{\prime}=1 \\
\text { atm Depth } \\
(\mathrm{m})\end{array}$} & \multicolumn{4}{|c|}{$\begin{array}{c}\text { MSF } \\
\text { (Reference Depth) }\end{array}$} & \multirow{3}{*}{$\begin{array}{c}\text { Critical } \\
\text { Depth (m) }\end{array}$} & \multicolumn{4}{|c|}{$\begin{array}{c}\text { MSF } \\
\text { (Critical Depth) } \\
\end{array}$} \\
\hline & \multirow{2}{*}{$\begin{array}{l}\text { Darfield } \\
\text { Eqk }\end{array}$} & \multirow{2}{*}{$\begin{array}{l}\text { Chch } \\
\text { Eqk }\end{array}$} & & \multicolumn{2}{|c|}{ Darfield Eqk } & \multicolumn{2}{|c|}{ Chch Eqk } & & \multicolumn{2}{|c|}{ Darfield Eqk } & \multicolumn{2}{|c|}{ Chch Eqk } \\
\hline & & & & Sea $75^{1}$ & $\mathrm{GT}_{05^{2}}$ & Sea75 & GT05 & & Sea75 & GT05 & Sea75 & GT05 \\
\hline CACS & 0.31 & 0.30 & 4.5 & 1.11 & 0.85 & 1.07 & 0.86 & 4.5 & 1.11 & 0.85 & 1.07 & 0.86 \\
\hline CBGS & 0.19 & 0.26 & 6.5 & 1.28 & 1.08 & 1.48 & 1.26 & 13.5 & 1.28 & 1.14 & 1.48 & 1.35 \\
\hline $\mathrm{CCCC}$ & 0.15 & 0.33 & 9.4 & 1.35 & 1.13 & 1.56 & 1.39 & 5.8 & 1.35 & 1.13 & 1.56 & 1.39 \\
\hline $\mathrm{CHHC}$ & 0.18 & 0.35 & 8.5 & 1.24 & 1.06 & 1.53 & 1.34 & 6.5 & 1.24 & 1.08 & 1.53 & 1.35 \\
\hline CMHS & 0.24 & 0.55 & 7.4 & 1.43 & 1.20 & 1.56 & 1.47 & 8.2 & 1.43 & 1.22 & 1.56 & 1.47 \\
\hline HPSC & 0.23 & 0.48 & 9.5 & 1.33 & 1.05 & 1.53 & 1.29 & 2.4 & 1.33 & 1.05 & 1.53 & 1.28 \\
\hline HVSC & 0.29 & 0.71 & 9.5 & 1.02 & 0.86 & 1.57 & 1.20 & 4.5 & 1.02 & 0.85 & 1.57 & 1.33 \\
\hline KPOC & 0.23 & 0.27 & 8.9 & 1.11 & 0.92 & 1.13 & 0.90 & 4.3 & 1.11 & 0.90 & 1.13 & 0.95 \\
\hline NNBS & 0.25 & 0.44 & 8.9 & 1.35 & 1.10 & 1.58 & 1.22 & 9.8 & 1.35 & 1.10 & 1.58 & 1.22 \\
\hline PPHS & 0.22 & 0.18 & 9.2 & 1.37 & 1.23 & 1.43 & 1.25 & 3.3 & 1.37 & 1.16 & 1.43 & 1.25 \\
\hline PRPC & 0.16 & 0.34 & 8.5 & 1.37 & 1.17 & 1.55 & 1.41 & 4.5 & 1.37 & 1.13 & 1.55 & 1.41 \\
\hline REHS & 0.14 & 0.37 & 10.5 & 1.41 & 1.07 & 1.66 & 1.38 & 2.6 & 1.41 & 1.17 & 1.66 & 1.45 \\
\hline RHSC & 0.46 & 0.49 & 6.3 & 1.19 & 1.05 & 1.30 & 1.21 & 4.8 & 1.19 & 1.04 & 1.30 & 1.18 \\
\hline SHLC & 0.24 & 0.49 & 7.5 & 1.15 & 0.91 & 1.60 & 1.32 & 4.5 & 1.15 & 0.91 & 1.60 & 1.34 \\
\hline SMTC & 0.16 & 0.18 & 9.8 & 1.19 & 0.95 & 1.40 & 1.20 & 11.5 & 1.19 & 0.97 & 1.40 & 1.22 \\
\hline
\end{tabular}

${ }^{1}$ Sea75 are MSF based on $\mathrm{n}_{\text {eqM }}$ computed using the Seed et al. (1975) approach

$588{ }^{2}$ GT05 are MSF based on $n_{\text {eqM }}$ computed using the Green and Terri (2005) approach 


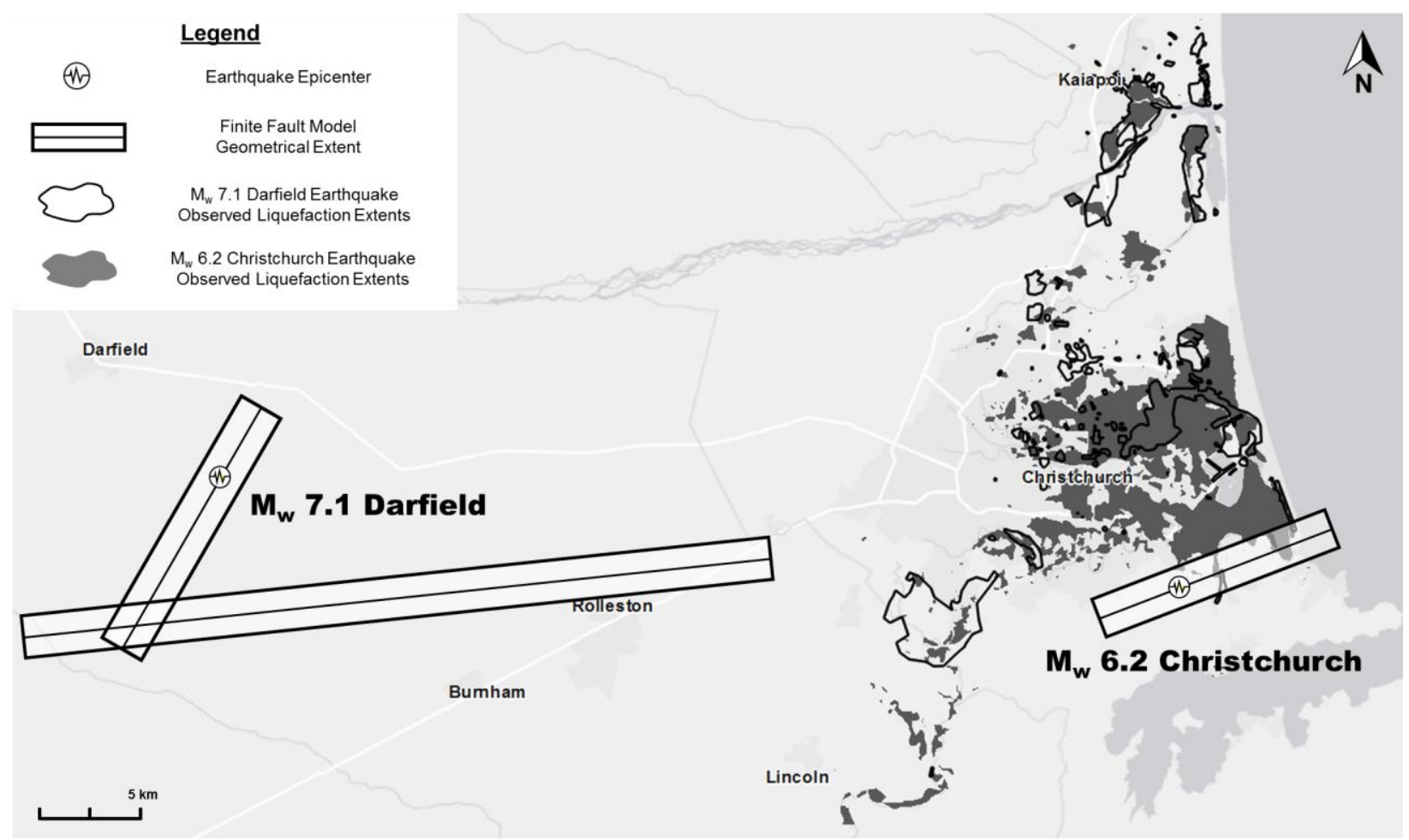

Figure 1. Ariel extents of liquefaction observed in Christchurch, NZ following the two largest events in the CES. Areas delineated in black represent liquefaction from the Sept. 4, $2010 \mathrm{M}_{\mathrm{w}}$ 7.1 Darfield earthquake. Areas highlighted in dark gray represent liquefaction from the Feb. 22, $2011 \mathrm{M}_{\mathrm{w}} 6.2$

Christchurch earthquake. The finite fault model boundaries shown are simplified from Holden et al. 


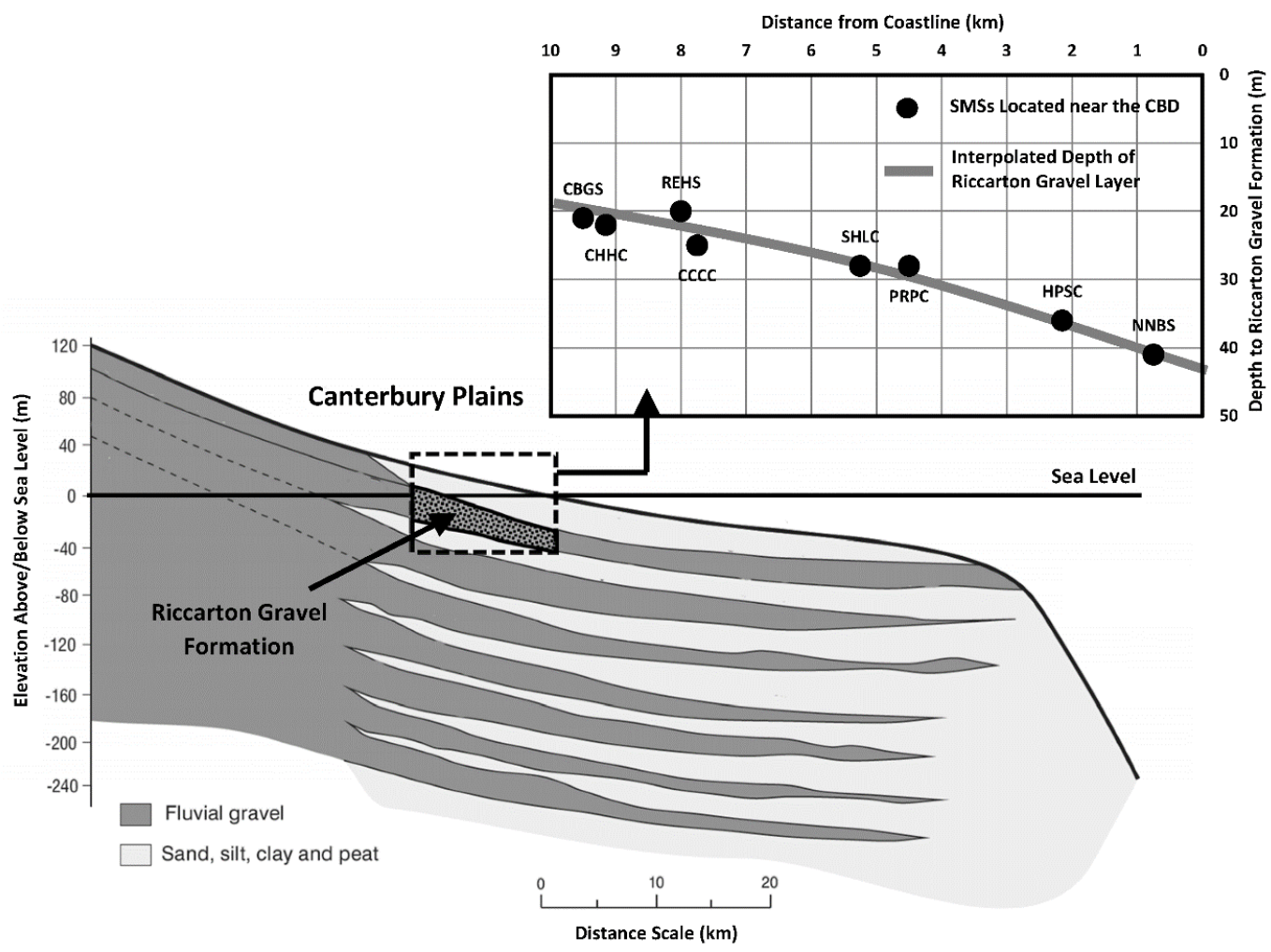

599 Figure 2. Geologic cross section of Christchurch showing the complexity of the interbedded sedimentary 600 deposits and depth to the Riccarton gravel formation for several SMSs (adopted from Forsyth et al., 2008 601 and Wotherspoon et al., 2015) 
604

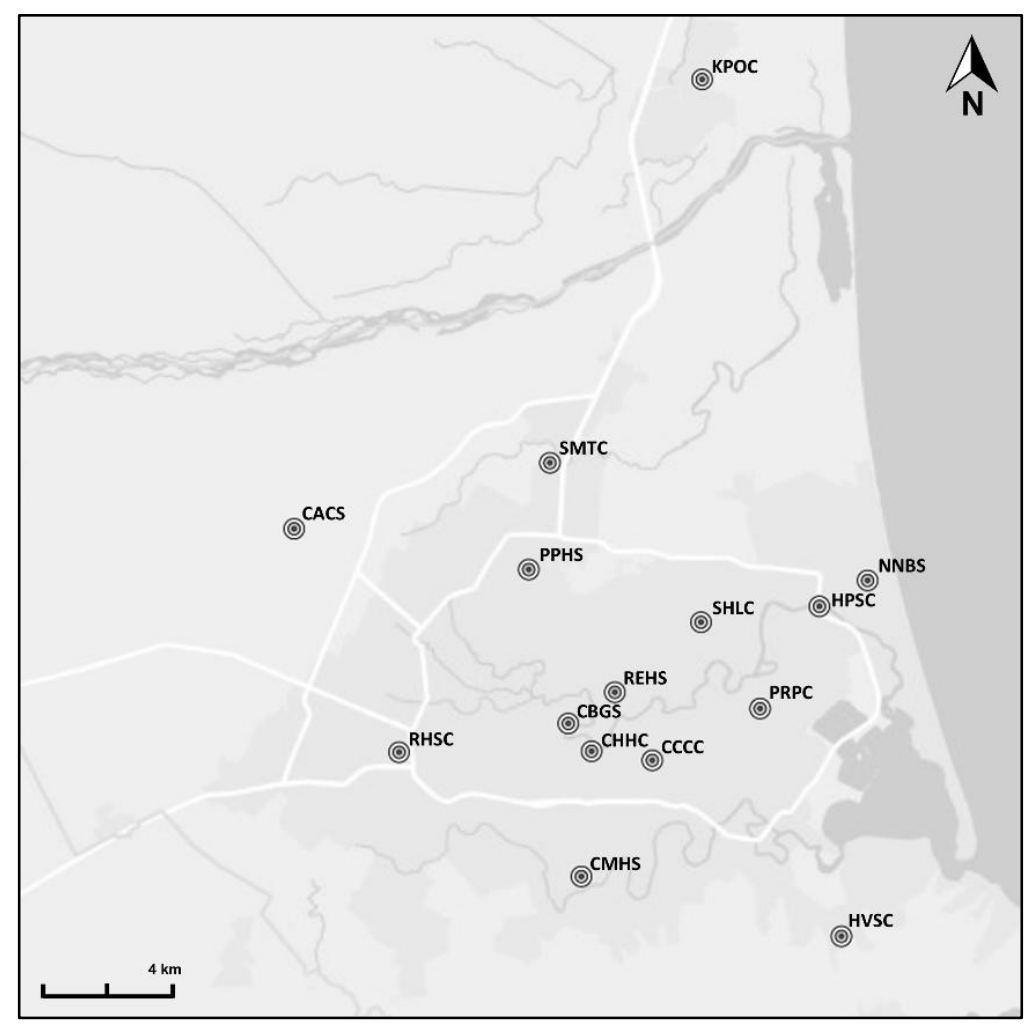

606

Figure 3. Overview of the fifteen SMS sites characterized by Wotherspoon et al. (2014, 2015a,b) and used 607 in this study.

608 


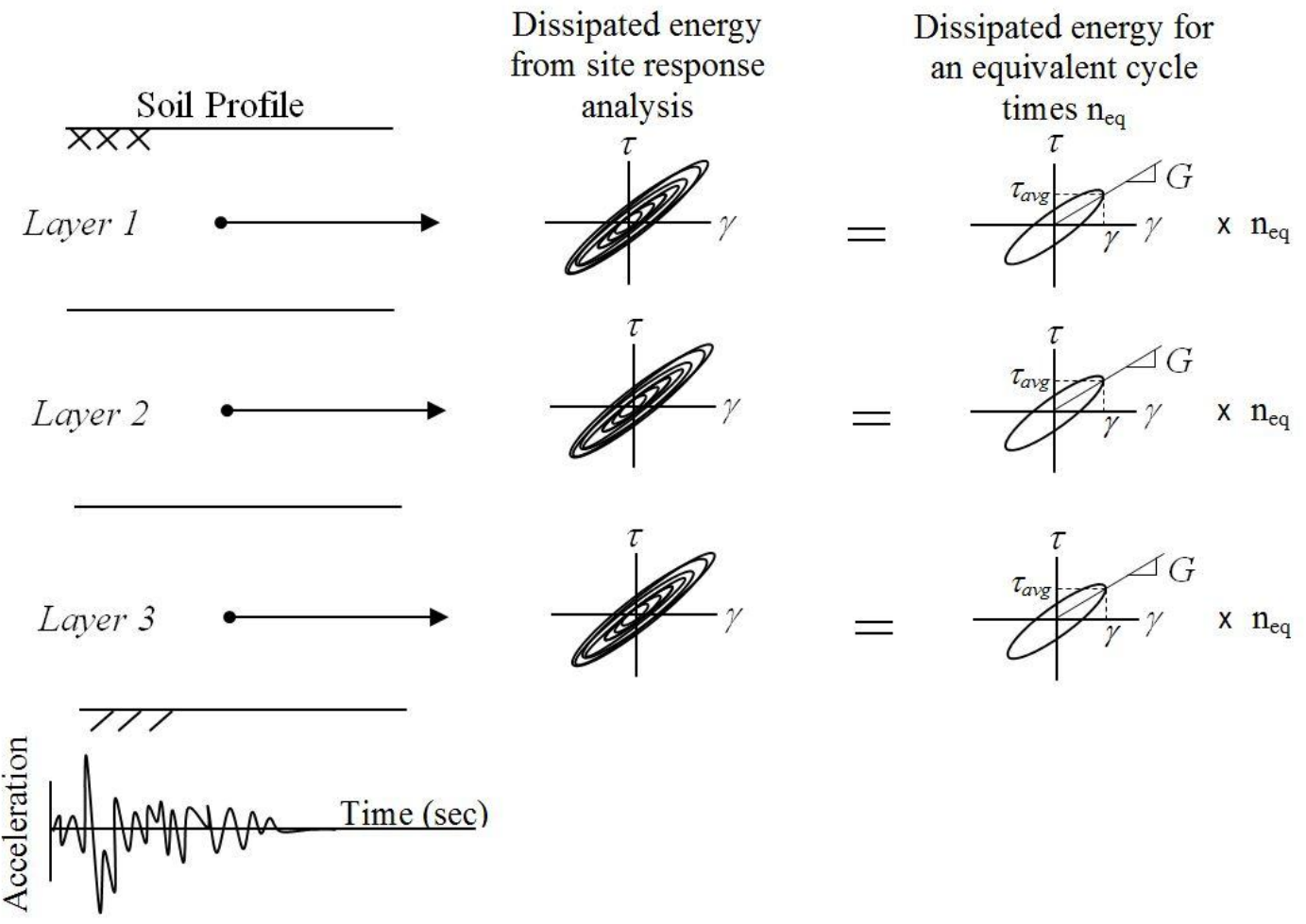

611

612

Figure 4. Illustration of the Green and Terri (2005) procedure to compute $\mathrm{n}_{\mathrm{eq}}$ (Green, 2001). 


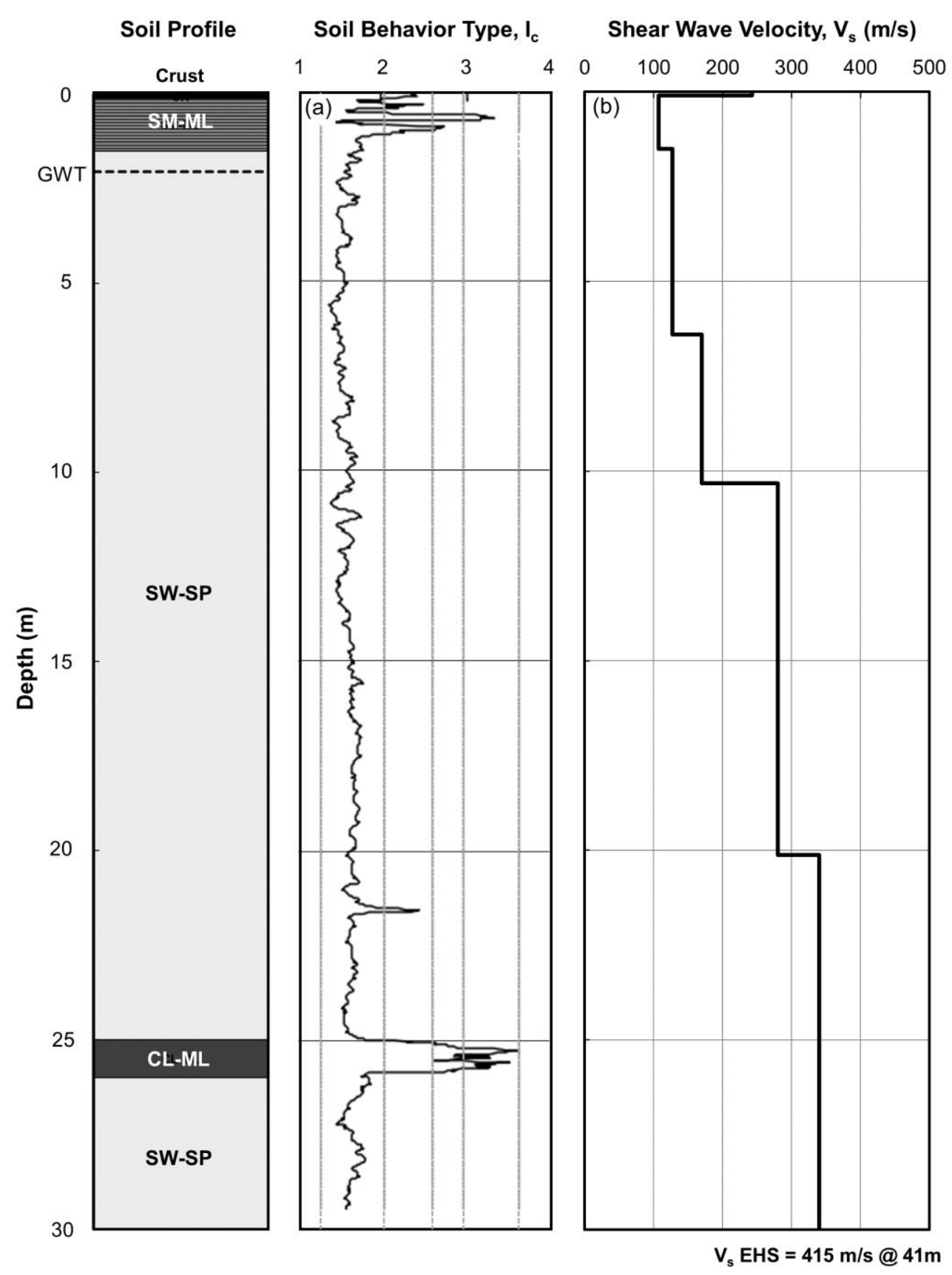

617 Figure 5. North New Brighton (NNBS) SMS soil profile along with profiles of: (a) CPT soil behavior 618 type index, and (b) shear wave velocity obtained by Wotherspoon et al.. 

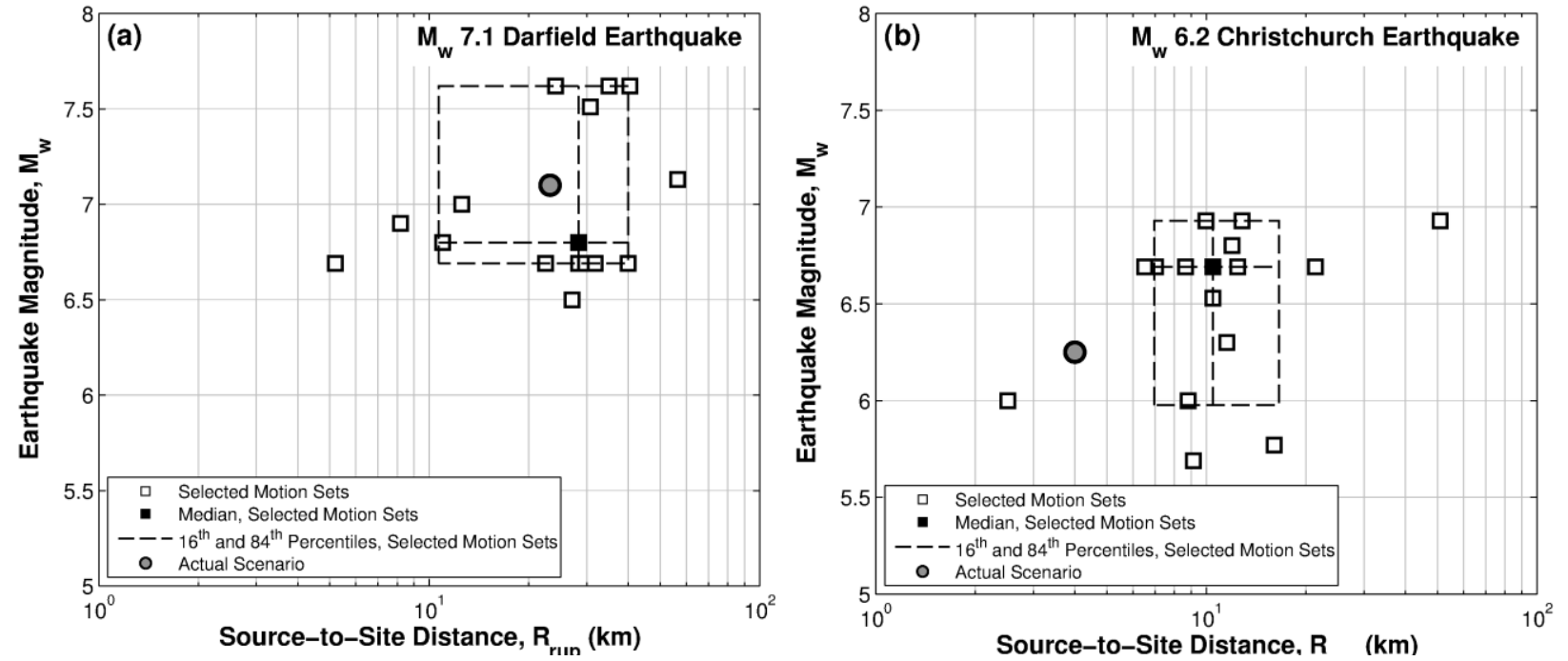

622

Figure 6. Distributions of causal parameters, $\mathrm{M}_{\mathrm{w}}$ and $\mathrm{R}_{\mathrm{rup}}$, for the selected motion sets for both the: (a) Darfield earthquake, and (b) Christchurch earthquake scenarios at the NNBS SMS site. 

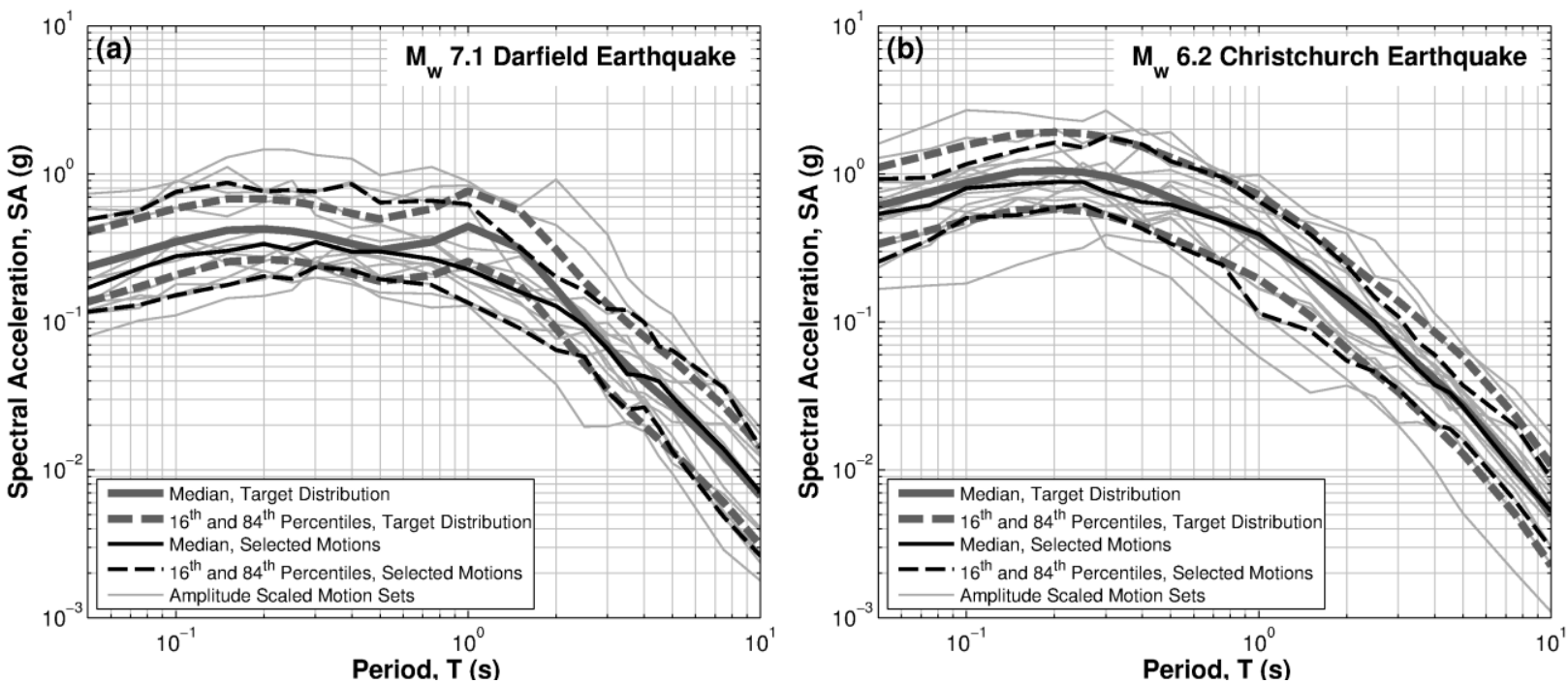

629 Figure 7.5\% damped response spectra of the target motions and selected motion for the NNBS SMS site 630 for the: (a) Darfield earthquake, and (b) Christchurch earthquake. 
631
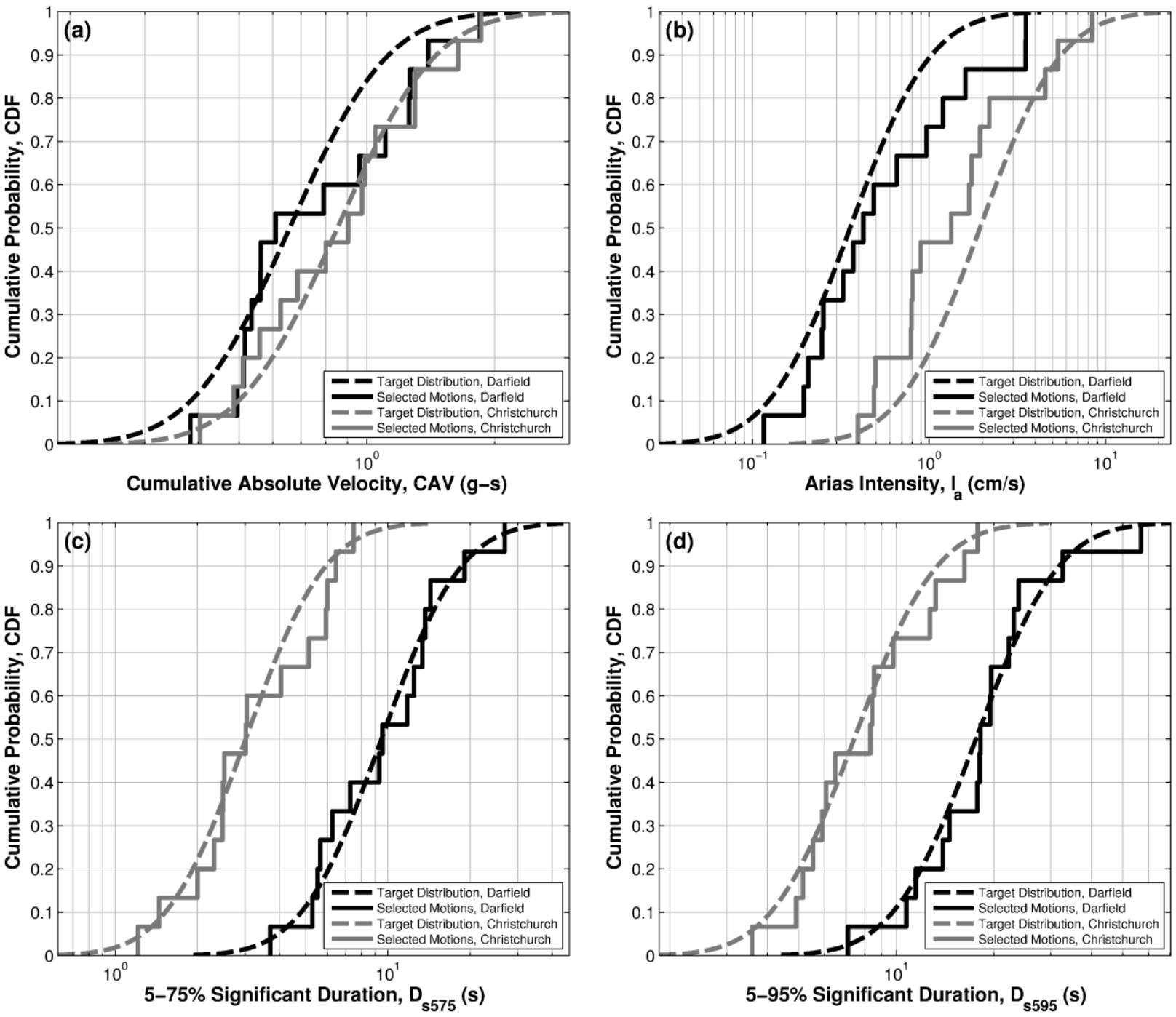

Figure 8. Cumulative distributions of the target and selected motions for the NNBS SMS site for both the 


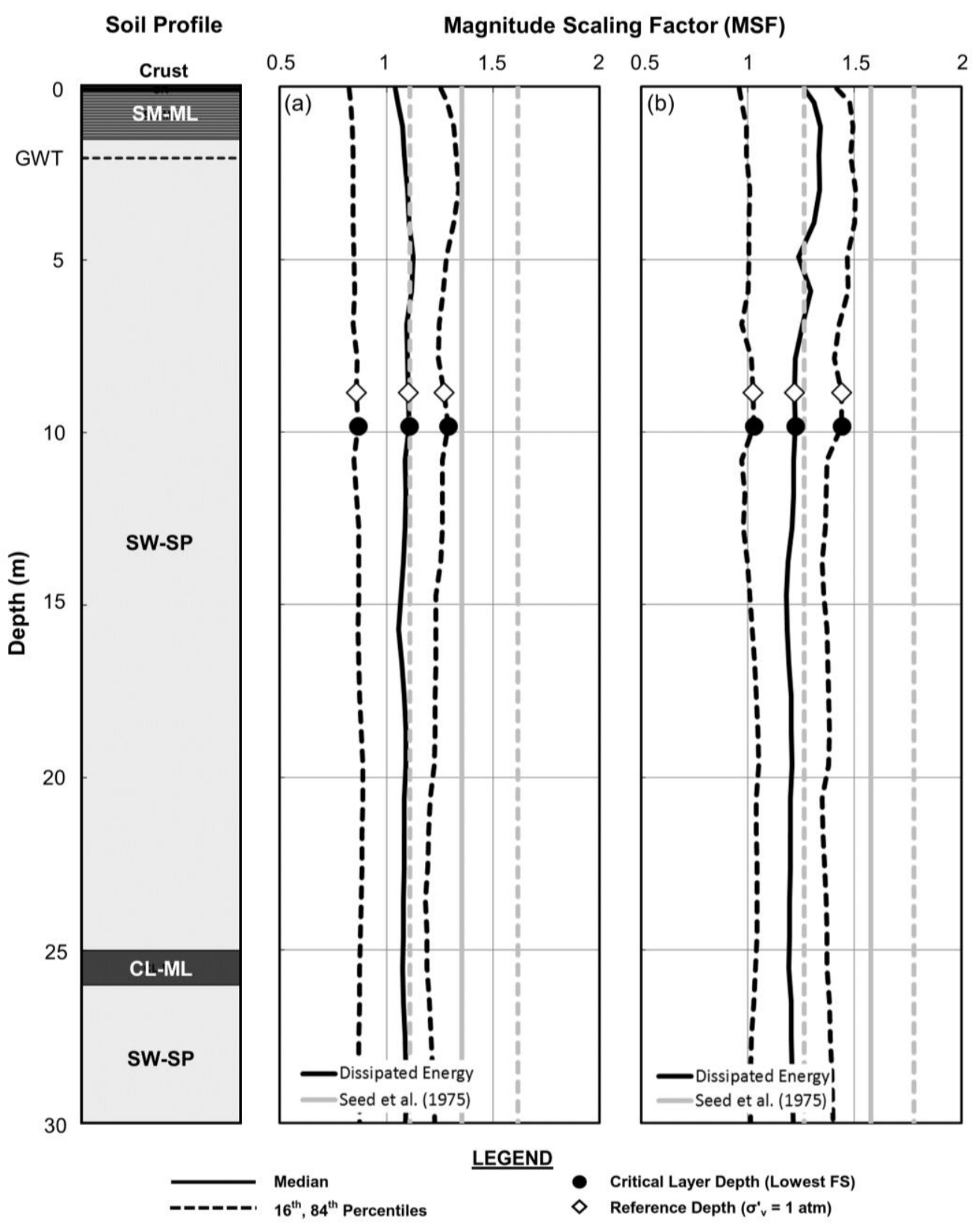

639 Figure 9. MSF computed for NNBS SMS site using the Green and Terri (2005) and Seed et al. (1975)

640 approaches for computing number of equivalent cycles for: (a) Darfield earthquake, and (b) Christchurch 641 earthquake. 


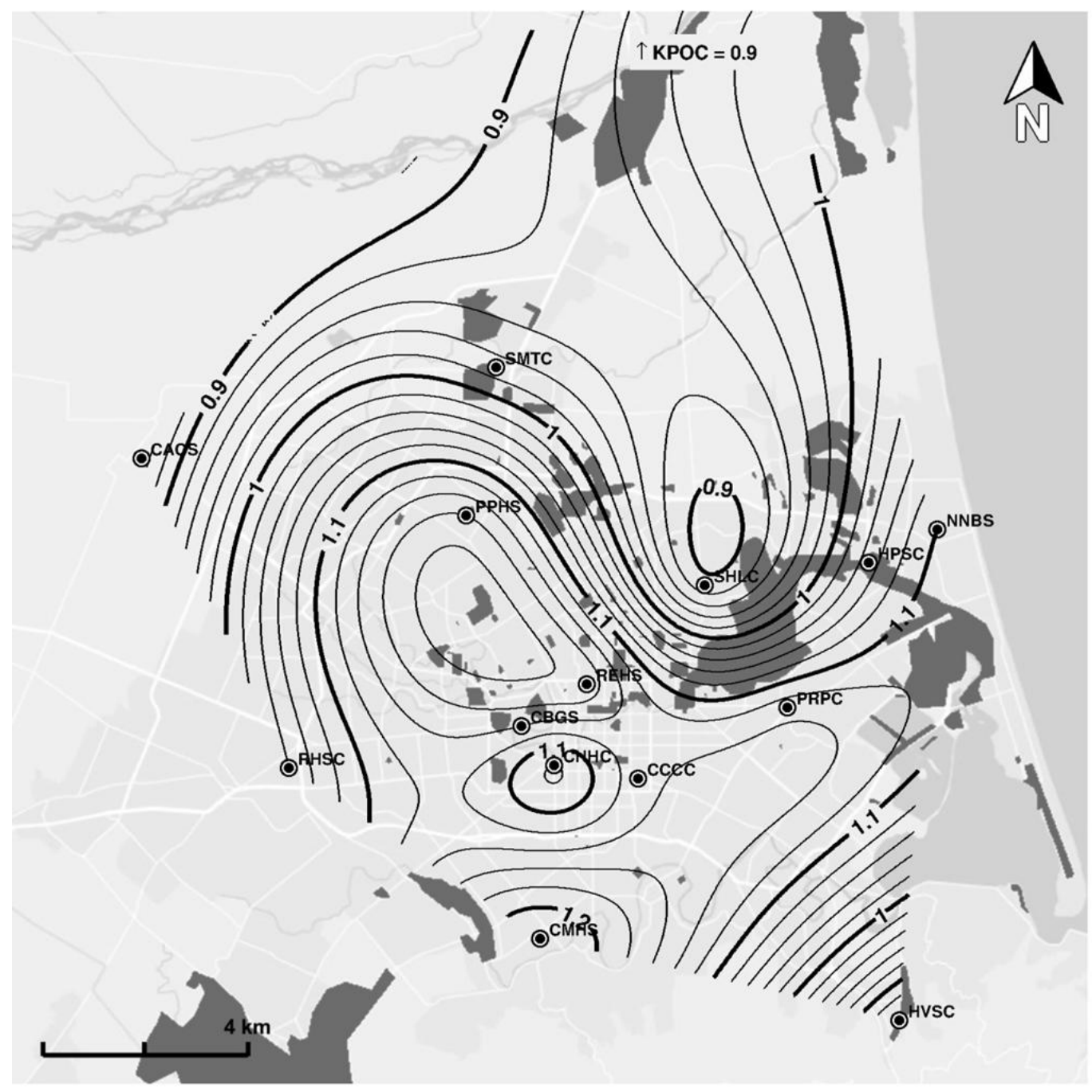

644

(a)

645 
646 647

648 649

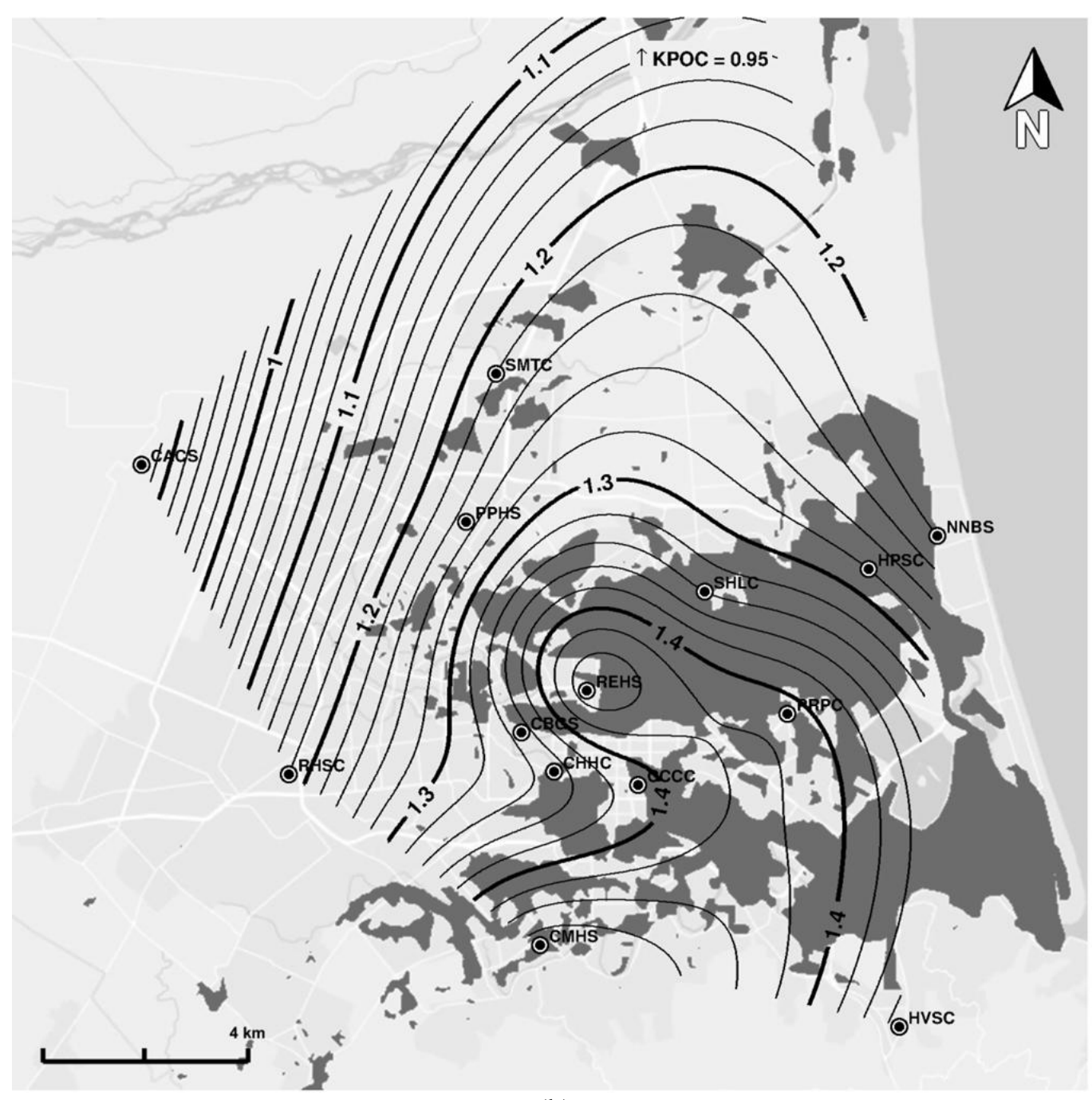

(b)

Figure 10. Contour plots of MSF computed using $\mathrm{n}_{\text {eqM }}$ from the Green and Terri (2005) approach for the: (a) Darfield earthquake, and (b) Christchurch earthquake. 


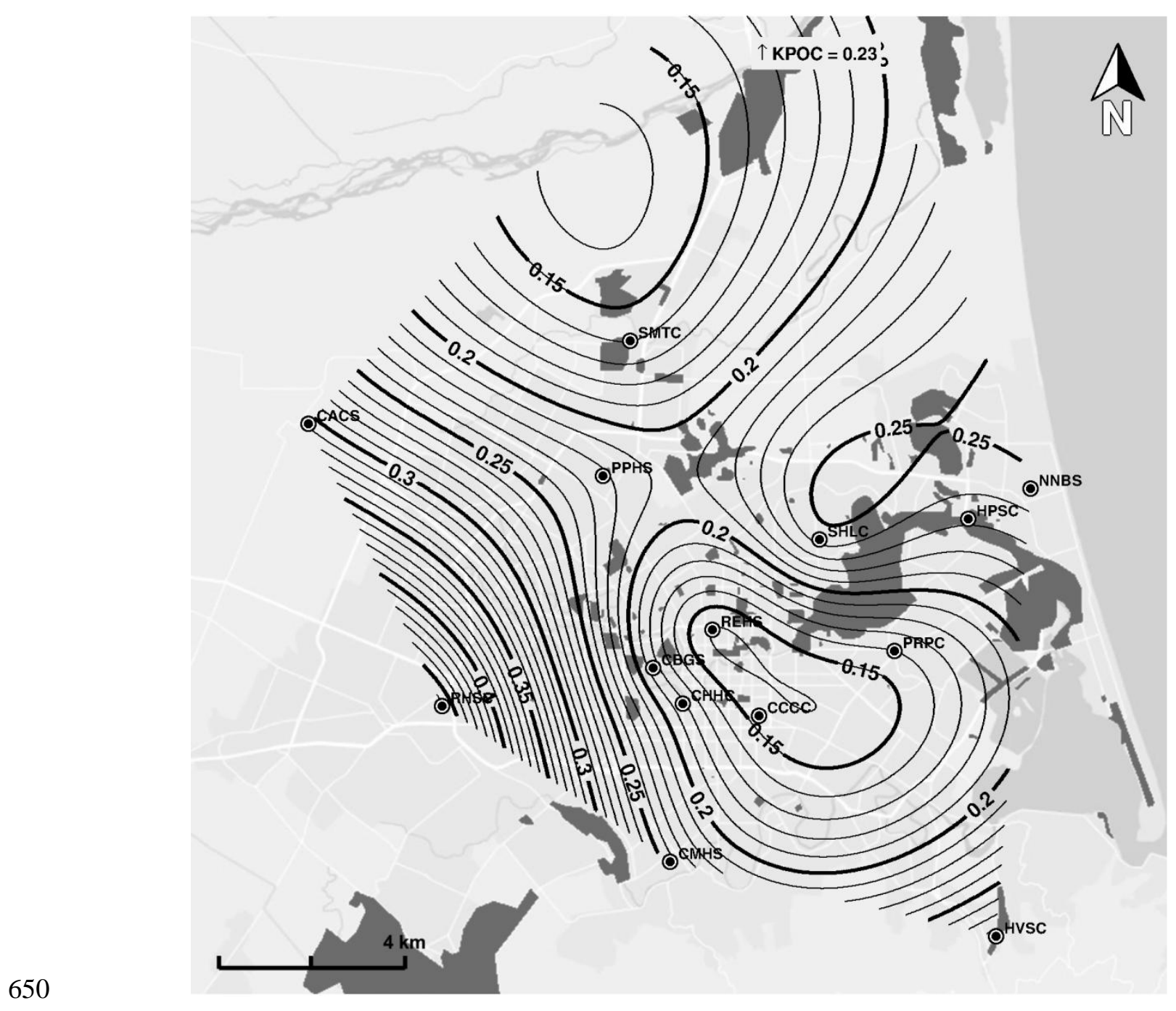

(a) 


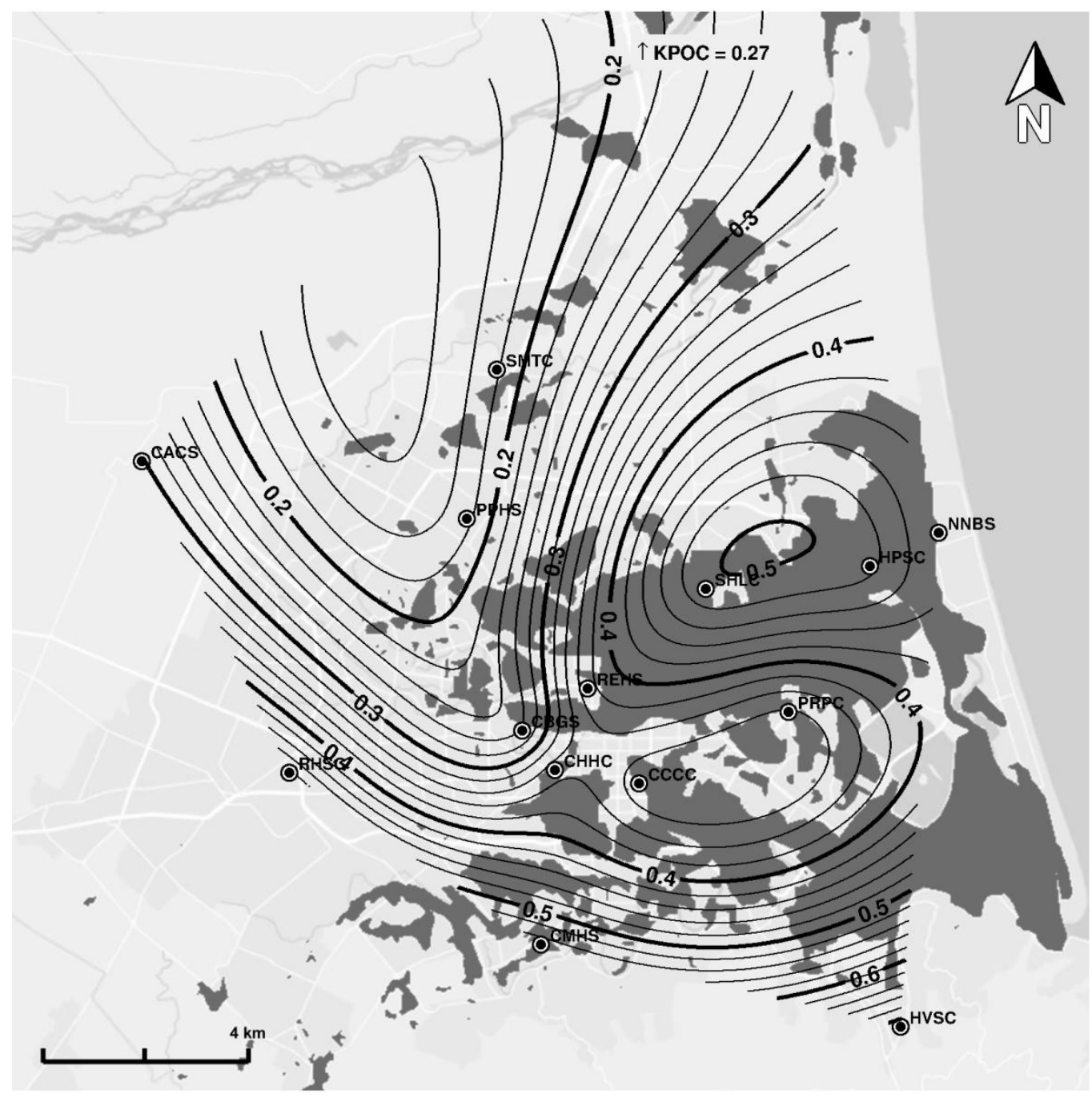
for the: (a) Darfield earthquake, and (b) Christchurch earthquake. 